
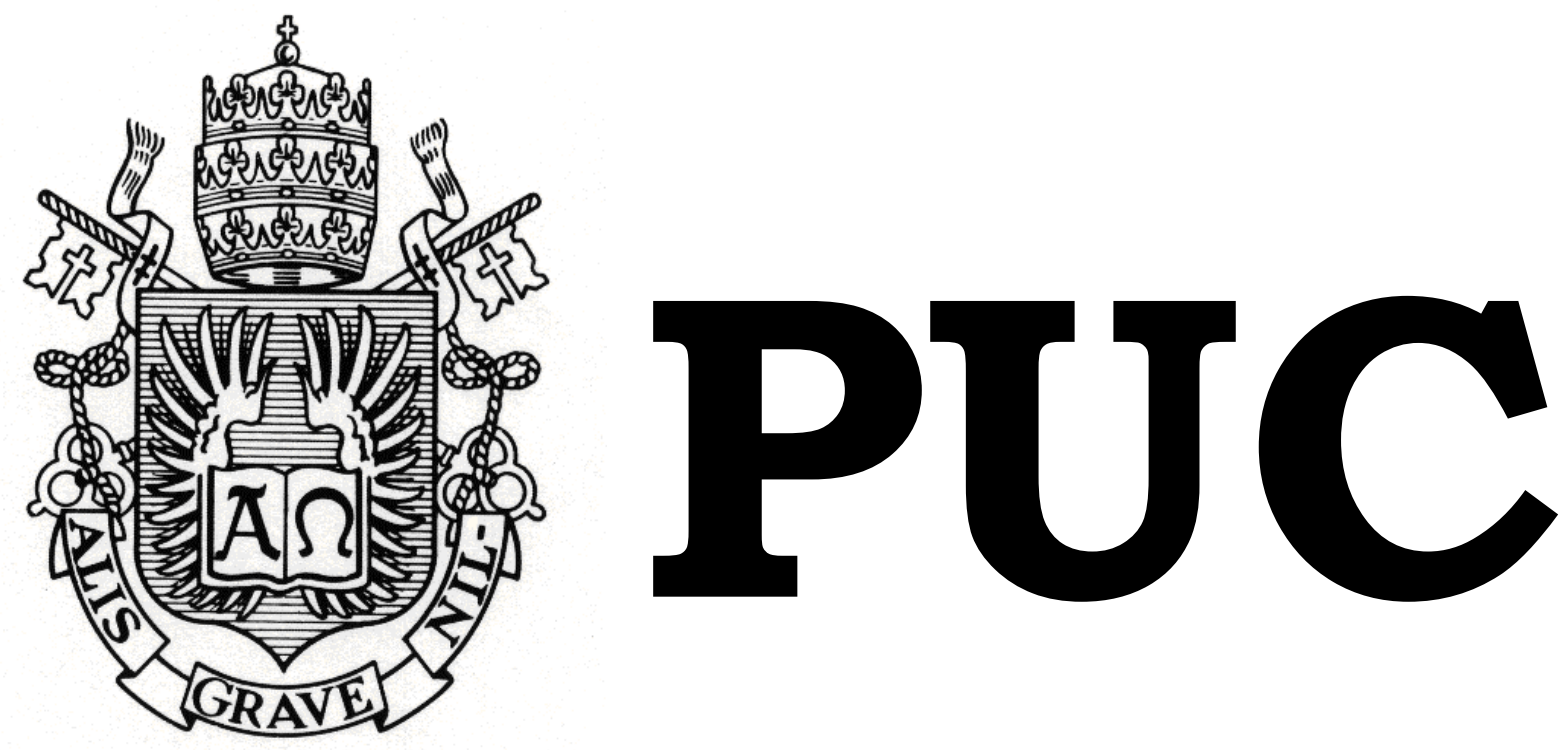

DEPARTAMENTO DE DIREITO

O DIREITO DAS SUCESSÕES NA UNIÃO HOMOAFETIVA

por

Bruna Marques Scarano da Silva

Orientador: Carlos Nelson Konder

Coorientadora: Thamis Dalsenter

2013.1

PONTIFÍCIA UNIVERSIDADE CATÓLICA DO RIO DE JANEIRO

RUA MARQUÊS DE SÃO VICENTE, 225 - CEP 22453-900

RIO DE JANEIRO - BRASIL 


\title{
O DIREITO DAS SUCESSÕES NA UNIÃO HOMOAFETIVA
}

\author{
por
}

\section{Bruna Marques Scarano da Silva}

Monografia apresentada ao Departamento de Direito da Pontifícia Universidade Católica do Rio de Janeiro (PUC-Rio) para a obtenção do Título de Bacharel em Direito.

Orientador: Carlos Nelson Konder Coorientadora: Thamis Dalsenter 


\section{AGRADECIMENTOS}

Aos meus pais, Denise e Sylvestre, por sempre terem acreditado e confiado em $\operatorname{mim}$.

À minha avó Mariuza, pelo amor incondicional e por ter estado presente em todos os momentos importantes da minha vida.

Aos meus irmãos, Filipe e Eduardo, os melhores que eu poderia ter.

Ao meu namorado, companheiro e melhor amigo Rodrigo, por todo amor, carinho e compreensão.

Ao meu orientador Carlos Konder e minha coorientadora Thamis Dalsenter por todas as explicações e suporte.

A todos vocês, meu muito obrigada. 


\section{RESUMO}

A presente monografia pretende analisar a sucessão do companheiro homoafetivo, considerando as recentes decisões do Supremo Tribunal Federal, Superior Tribunal de Justiça e Conselho Nacional de Justiça acerca da união entre pessoas do mesmo sexo. Aborda a falta de previsão legal da questão e defende a possibilidade da união homoafetiva com fulcro em princípios constitucionais. Na seara do Direito das Sucessões, analisa as diferenças entre o direito sucessório do cônjuge e do companheiro. Procura-se então definir qual o lugar ocupado pelo companheiro homoafetivo na sucessão, fazendo uma análise de como os tribunais veem decidindo antes e após a decisão do STF na ADI $n^{\circ}$ 132 que reconheceu o caráter de entidade familiar à união homoafetiva.

\section{Palavras-Chave:}

União homoafetiva. Homossexualidade. Direito das Sucessões. Sucessão do cônjuge e do companheiro. Sociedade de Fato. União estável e casamento civil entre pessoas do mesmo sexo. Entidade familiar. Afetividade. Privacidade. Intimidade. Isonomia. Igualdade. Pluralismo das entidades familiares. 


\section{SUMÁRIO}

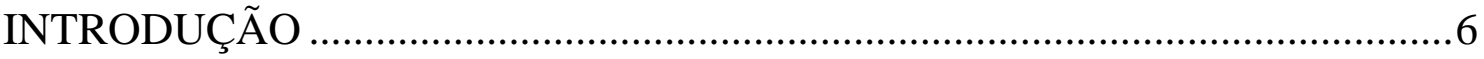

1. A Família Homoafetiva: previsão legal e omissão legislativa ..........................9

1.1. Homossexualidade e a família homoafetiva. ..............................................9

1.2. A União entre pessoas do mesmo sexo sob a ótica constitucional .................12

1.3. Omissão do Poder Legislativo ....................................................................... 16

2. O Direito sucessório do cônjuge e do companheiro .......................................21

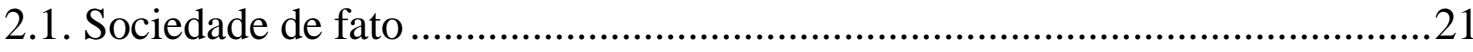

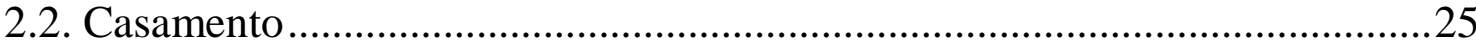

2.2.1. Direitos Sucessórios no Casamento - A Controversa Sucessão do Cônjuge

2.2.2. A possibilidade do casamento entre pessoas do mesmo sexo ...................33

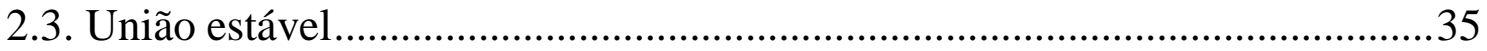

3. O reconhecimento da união homoafetiva como entidade familiar e a sucessão

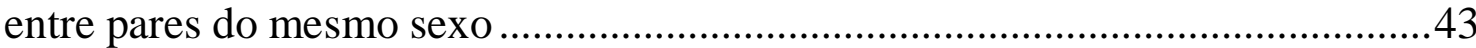

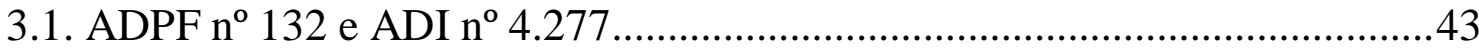

3.2. O Direito Sucessório na União Homoafetiva .............................................44

Conclusão .50

Referências Bibliográficas 


\section{LISTA DE ABREVIAÇÕES}

§: Parágrafo

ADI: Ação Direta de Inconstitucionalidade

ADPF: Arguição de Descumprimento de Preceito Fundamental

Art.: Artigo

CF: Constituição Federal

CC: Código Civil

CC/02: Código Civil de 2002

CC/16: Código Civil de 1916

CJF: Conselho de Justiça Federal

CNJ: Conselho Nacional de Justiça

CRFB: Constituição da República Federativa do Brasil

IBDFAM: Instituto Brasileiro de Direito de Família

LICC: Lei de Introdução às normas do Direito Brasileiro

MS: Mandado de Segurança

PEC: Proposta de Emenda Constitucional

PL: Projeto de Lei

PLC: Projeto de Lei da Câmara

PSC: Partido Social Cristão

Rel.: Relator

Resp.: Recurso Especial

STJ: Superior Tribunal de Justiça

STF: Supremo Tribunal Federal

TJRJ: Tribunal de Justiça do Estado do Rio de Janeiro

TJRS: Tribunal de Justiça do Estado do Rio Grande do Sul 


\section{INTRODUÇÃO}

O presente trabalho tem por objetivo examinar a situação jurídica atual da família homoafetiva, considerando os recentes avanços na jurisprudência brasileira e enfatizando o direito sucessório.

Primeiramente, após breve comentário sobre a homossexualidade, analisaremos a homoafetividade sob a ótica constitucional. Como não há previsão legal específica, a defesa dos direitos homossexuais encontra fundamento em princípios fundamentais, tais como da igualdade, isonomia, privacidade, intimidade, respeito à diferença, pluralismo das entidades familiares e afetividade. Todavia, a mesma Constituição que dispõe sobre princípios tão amplos e até mesmo utópicos, estatui que para efeitos de proteção do Estado, é reconhecida a união estável entre homem e mulher. Tal distinção que acaba por excluir pares do mesmo sexo será analisada uma vez que destoa no meio de tantas garantias asseguradas pela Magna Carta.

Deste modo, a existência e aplicação de princípios constitucionais não é suficiente para garantir o reconhecimento da união homoafetiva e tutelar seus efeitos jurídicos. Desta forma, caberá analisar a importância do papel do Poder Legislativo que ao editar leis confere segurança jurídica nas relações. Infelizmente, com a exceção de algumas manifestações, os parlamentares quedam-se inertes.

Devido a omissão legislativa, o Poder Judiciário diante da impossibilidade de negar prestação jurisdicional, passou a decidir casos concretos que lhe eram submetidos. Entretanto, a ausência de previsão legal fez com que não houvesse uma jurisprudência uniforme, o que levava cada magistrado a decidir de acordo com suas concepções: ora a união homoafetiva era admitida, variando entre o reconhecimento sociedade de fato, união estável e até mesmo casamento, ora negada. 
Em seguida, examinaremos o direito das sucessões na sociedade de fato, no casamento e na união estável, relacionando a aplicação de tais institutos à união homoafetiva.

Inicialmente, cabe destacar que na sociedade de fato não ocorre uma sucessão propriamente dita. Trata-se de solução encontrada pelos tribunais para garantir direitos patrimoniais ao companheiro sobrevivente. Entretanto, a aplicação do instituto demonstrou não ser a mais adequada, pois considerando que a sociedade de fato pertence ao direito obrigacional, os companheiros são tratados como "sócios", sendo desconsiderado o afeto presente no relacionamento entre ambos.

Logo após, nos debruçamos sobre o estudo do direito sucessório do cônjuge. Considera-se de suma importância para o presente trabalho dissecar o inciso I do art. 1.829 do $\mathrm{CC} / 02$ referente à concorrência entre cônjuge e descendentes. A controvérsia acerca do assunto é esclarecida pela Ministra Nancy Andrighi no Recurso Especial nº 992.749 após apresentar três correntes doutrinárias divergentes.

Após o exame da sucessão do cônjuge, discute-se sobre a possibilidade do casamento civil ser aceito pelo ordenamento jurídico brasileiro. Destaca-se a importância da recente Resolução $n^{\circ} 175$ editada pelo Conselho Nacional de Justiça que proibiu a recusa pelas autoridades competentes da habilitação, celebração de casamento civil ou de conversão de união estável em casamento entre pessoas de mesmo sexo.

No que tange à sucessão do companheiro, a principal discussão gira em torno do art. 1.790 do Código Civil de 2002 que dispõe que o companheiro participará da sucessão apenas quanto aos bens adquiridos onerosamente na vigência da união.

Por fim, será apreciada com maior profundidade a decisão do Supremo Tribunal Federal no julgamento conjunto da Arguição de Descumprimento de Preceito Fundamental (ADPF) n 132/RJ e da Ação 
Direta de Inconstitucionalidade (ADI) $n^{\circ} 4.277 / \mathrm{DF}$, seus efeitos vinculantes e suas consequências para a união homoafetiva.

Finalmente, analisaremos como o Poder Judiciário vem decidindo acerca do direito sucessório nas uniões homoafetivas e se ocorreram mudanças após o julgamento da ADPF 132 na qual o STF decidiu atribuir status de entidade familiar às uniões homoafetivas. 


\section{A Família Homoafetiva: previsão legal e omissão legislativa}

\subsection{Homossexualidade e a família homoafetiva.}

A Constituição da República Federativa do Brasil de 1988 admite diversos modelos de família, seja constituída pelo casamento ou união estável, monoparental ou concubinária. Com a evolução do conceito de família, o afeto passa a prevalecer sobre concepção tradicional e patriarcal de família, abrindo espaço, inclusive, para as uniões entre pessoas do mesmo sexo.

No mesmo sentido, concluíram os ministros do Supremo Tribunal Federal no julgamento da ADPF $n^{\circ} 132$ e da ADI no 4.277 que a afetividade prevalece sobre fatores biológicos.

$\mathrm{Ou}$ "homoafetivamente", como hoje em dia mais e mais se fala, talvez para retratar o relevante fato de que o século XXI já se marca pela preponderância da afetividade sobre a biologicidade. Do afeto sobre o biológico, este último como realidade tão-somente mecânica ou automática, porque independente da vontade daquele que é posto no mundo como consequência da fecundação de um individualizado óvulo por um também individualizado espermatozóide ${ }^{1}$.

Destaca-se ainda no acórdão que a preferência sexual é direito fundamental e bem de personalidade, que se põe como direta emanação do princípio da "dignidade da pessoa humana". O direito à busca da felicidade também é mencionado:

"Afinal, se as pessoas de preferência heterossexual só podem se realizar ou ser felizes heterossexualmente, as de preferência homossexual seguem na mesma toada: só podem se realizar ou ser felizes homossexualmente" ${ }^{2}$. (grifo do autor)

Sobre a origem e a causa da homossexualidade, não há explicação precisa, apesar dos esforços da psicologia e da medicina. Entretanto, não há dúvidas de que as relações entre pares do mesmo sexo existem desde a antiguidade.

\footnotetext{
${ }^{1}$ STF, ADPF no 132, Relator Ministro Ayres Britto, Brasília, 05 de maio de 2011.

${ }^{2}$ Ibid.
} 
"O fato é que a homossexualidade acompanha a história do homem, Sabe-se da sua existência desde os primórdios dos tempos gregos. Não é crime nem pecado; não é uma doença nem um vício. Também não é um mal contagioso, nada justificando a dificuldade que as pessoas têm de conviver com homossexuais. É simplesmente uma outra forma de viver" ${ }^{3}$.

No que tange às diversas formas de expressão que designam a preferência por pessoas do mesmo sexo, algumas inclusive pejorativas, utilizaremos o termo "homossexualidade". Não é adequada a utilização da expressão homossexualismo, pois o sufixo "ismo" qualifica doenças ${ }^{4}$. O correto é referir-se como homossexualidade, pois o sufixo "dade" expressa condição ou estado.

Discordo também da expressão "opção sexual". Ora, não há uma opção. $\mathrm{O}$ indivíduo simplesmente é homossexual, assim como o heterossexual não escolhe ser "hetero". Por tal condição ser nata, assim como a cor e o sexo, os homossexuais não podem ser discriminados, muito menos pela própria legislação que por ser omissa limita diversos direitos, dentre eles o de herança.

O Conselho Federal de Psicologia ao baixar a Resolução nº 1, de 23 de março de 1999, estabeleceu que nenhum psicólogo deverá tratar a homossexualidade como uma patologia e nem oferecer nenhum tipo de tratamento objetivando sua cura, pois não se trata de um transtorno psíquico. Ademais, os psicólogos não poderão fazer qualquer tipo de pronunciamento público que corrobore com o preconceito contra homossexuais.

\footnotetext{
"Resolução no 1/1999

Art. $3^{\circ}$ - os psicólogos não exercerão qualquer ação que favoreça a patologização de comportamentos ou práticas homoeróticas, nem adotarão ação coercitiva tendente a orientar homossexuais para tratamentos não solicitados.

Parágrafo único - Os psicólogos não colaborarão com eventos e serviços que proponham tratamento e cura das homossexualidades.

Art. $4^{\circ}$ - Os psicólogos não se pronunciarão, nem participarão de pronunciamentos públicos, nos meios de comunicação de massa, de modo a
}

\footnotetext{
${ }^{3}$ DIAS, Maria Berenice. Manual de Direito das Famílias, Editora Revista dos Tribunais, $6^{\mathrm{a}}$ Edição, 2010, São Paulo, p. 197.

${ }^{4}$ DIAS, Maria Berenice. Manual de Direito das Famílias, p. 197.
} 
reforçar os preconceitos sociais existentes em relação aos homossexuais como portadores de qualquer desordem psíquica".

Infelizmente, o avanço da Resolução do Conselho Federal de Psicologia foi ameaçado pelo Projeto de Decreto Legislativo 234/2011 ${ }^{5}$ que visa sustar a aplicação do parágrafo único do art. $3^{\circ}$ e o art. $4^{\circ}$. No projeto, argumenta-se que o Conselho Federal de Psicologia extrapolou o seu poder regulamentar, usurpando a competência do Poder Legislativo.

A legalização da união entre pessoas do mesmo sexo enfrenta diversos obstáculos. Homossexuais são constantes alvos de discriminação e violência por uma parte da sociedade ainda extremamente conservadora e preconceituosa. O legislativo, por sua vez, teme editar leis regulando a situação dos homossexuais uma vez que poderá perder votos. Por fim, há também intolerância por parte das instituições religiosas. Algumas, inclusive, consideram a homossexualidade como uma doença passível de cura, chegando a oferecer tratamento. Nesse sentido, Maria Berenice Dias destaca: "A igreja fez do casamento a forma de propagar a fé cristã: crescei e multiplicai-
vos. A infertilidade dos vínculos homossexuais levou a repudiá-los, acabando por
serem relegados à margem da sociedade"6.

Entretanto, com o alargamento do conceito de entidade familiar para além do casamento e considerando o avanço da ciência que permite métodos como o da reprodução assistida, não há mais razão para que o conceito de família se limite à união heterossexual constituída pelos laços do matrimônio ${ }^{7}$. Dessa forma, nada justifica impor limites à legalização da união entre pares do mesmo sexo.

\footnotetext{
${ }^{5}$ Disponível em <http://www.camara.gov.br/proposicoesWeb/prop_mostrarintegra;jsessionid=1E3DEE05969B392 F34319E4895CE9B19.node1 ? codteor $=887984 \&$ filename=Avulso+-PDC+234/2011>. Acesso em 10 de abril de 2013.

${ }^{6}$ DIAS, Maria Berenice. Manual de Direito das Famílias, p. 197

${ }^{7}$ DIAS, Maria Berenice. Quer casar comigo?. Artigo publicado em 20 de maio de 2013. Disponível em <http://direitohomoafetivo.com.br/anexos/artigo/93_ae90d48e5fc797525b95497e6f69d511.pdf> Acesso em 29 de maio de 2013.
} 
O último censo $^{8}$ revelou a existência de 60 mil famílias homoafetivas. Entretanto, de acordo com Maria Berenice Dias, o número não importa. Em sua lição, a autora assinala que além de preconceito, perseguições e violência sofrida, não se pode condenar à invisibilidade e deixar parcela da população fora do âmbito da tutela jurídica ${ }^{9}$. Ademais, salienta que o direito à tratamento igualitário independe da tendência afetiva e defende a sexualidade como um direito:

"A sexualidade é um elemento integrante da própria natureza e abrange a dignidade humana. Todos têm o direito de exigir respeito ao livre exercício da sua sexualidade. Sem liberdade sexual, o indivíduo não se realiza, tal como ocorre quando lhe falta qualquer outra das chamadas liberdades ou direitos fundamentais. $\mathrm{O}$ direito de tratamento igualitário independente da tendência sexual" ${ }^{10}$.

\subsection{A União entre pessoas do mesmo sexo sob a ótica constitucional}

A Constituição garante a liberdade e igualdade e veda a discriminação por motivo de origem, raça, sexo ou idade, assegurando o exercício dos direitos sociais e individuais, a liberdade, a segurança, o bemestar, o desenvolvimento, a igualdade e a justiça como valores supremos de uma sociedade fraterna, pluralista e sem preconceitos $^{11}$.

A possibilidade da união estável e casamento entre pessoas do mesmo sexo encontra respaldo em diversos princípios constitucionais. O art. $5^{\circ}$ da CRFB consagra o princípio da igualdade e o princípio da isonomia ao proclamar que "todos são iguais perante a lei, sem distinção de qualquer natureza". Dessa forma, não compete ao ordenamento jurídico limitar ou até mesmo negar direitos levando em consideração a orientação sexual.

\footnotetext{
8 O Censo 2010 quantificou famílias homoafetivas. Disponível em $<$ http://oglobo.globo.com/economia/vida-com-dois-pais-duas-maes-5902254>. Acesso em 03 de junho de 2013.

${ }_{9}^{9}$ DIAS, Maria Berenice. A Consagração Constitucional da Homoafetividade. Revista Magister de Direito Civil e Processual Civil, p. 95

10 DIAS, Maria Berenice. Um novo direito: Direito Homoafetivo. Disponível em <http://www.mariaberenice.com.br/uploads/55_-_um_novo_direito_-_direito_homoafetivo.pdf>. Acesso em 05 de junho de 2013

${ }^{11}$ DIAS, Maria Berenice, Manual de Direito das Famílias, p. 199
} 
Também é compromisso do Estado garantir a dignidade humana, e o respeito à privacidade e intimidade, não cabendo ao direito intervir nas relações pessoais de cada indivíduo, apenas respeitá-las e regulá-las quando lhe incumbir.

Ademais, devem ser observados os princípios constitucionais da famíliaa $^{12}$, tais como o da igualdade de respeito a diferença, do pluralismo das entidades familiares e da afetividade.

Entretanto, a despeito dos diversos princípios constitucionais que respaldam a possibilidade de tratamento igualitário entre casais heterossexuais e homossexuais, conforme preceitua o $\S 3^{\circ}$ do art. 226 da CRFB, "para efeito de proteção do Estado, é reconhecida a união estável entre homem e mulher como entidade familiar, devendo a lei facilitar sua conversão em casamento". (grifos nossos)

Merece destaque o fato de que dispositivo constitucional em comento reconhece a união estável somente entre homem e mulher. Dessa forma, interpretando literalmente o texto constitucional, conclui-se que a diversidade de sexos é requisito natural do casamento e da união estável, " $a$ ponto de serem consideradas inexistentes uniões homossexuais" ${ }^{\prime 13}$. A mesma exigência se repete nos artigos $1.514^{14}, 1.565^{15}$ e $1.723^{16}$ do Código Civil de 2002.

\footnotetext{
12 Ibid., p. 61

13 GONÇALVES, Carlos Roberto. Direito Civil Brasileiro. Direito de Família. São Paulo: Saraiva, 2005, v. VI, p. 28 In VARGAS, Fábio. União Homoafetiva: Direito Sucessório e Novos Direitos, $2^{\text {a }}$ Edição, Curitiba: Editora Juruá, 2011, p. 52.

${ }^{14} \mathrm{CC} / 2002$. Art. 1.514. O casamento se realiza no momento em que o homem e a mulher manifestam, perante o juiz, a sua vontade de estabelecer vínculo conjugal, e o juiz os declara casados.

${ }^{15}$ CC/2002. Art. 1.565. Pelo casamento, homem e mulher assumem mutuamente a condição de consortes, companheiros e responsáveis pelos encargos da família

${ }^{16} \mathrm{CC} / 2002$. Art. 1.723. É reconhecida como entidade familiar a união estável entre o homem e a mulher, configurada na convivência pública, contínua e duradoura e estabelecida com o objetivo de constituição de família.
} 
Apesar da evolução trazida pela CRFB ao tutelar relações fora do instituto do matrimônio, perdeu-se a oportunidade de contemplar, expressamente, a união homossexual como entidade familiar. ${ }^{17}$

Acerca da matéria em comento, depreende-se da lição de Maria Berenice Dias que o $\S 3^{\circ}$ do art. 226 da CRFB consiste em cláusula geral de inclusão:

\begin{abstract}
"A Constituição, rastreando os fatos da vida, viu a necessidade de reconhecer a existência de relações afetivas fora do casamento. Assim, emprestou especial proteção às entidades familiares formadas por um dos pais e sua prole, bem como à união estável entre homem e mulher (CF 226). Esse elenco, no entanto, não esgota as formas de convívio merecedoras de tutela. Trata-se de cláusula geral de inclusão, não sendo admissível excluir qualquer entidade que preencha os requisitos de afetividade, estabilidade e ostensibilidade. Não se pode deixar de reconhecer que há relacionamentos que, mesmo sem a diversidade de sexos atendem a tais requisitos. Têm origem em um vínculo afetivo, devendo ser identificados como entidade a merecer a tutela legal"18.
\end{abstract}

Preenchidos os requisitos essenciais para a configuração da união estável, tais como a afetividade, estabilidade, ostensibilidade e o desejo de constituir família, Paulo Lôbo defende que há proteção constitucional à união entre pessoas do mesmo sexo. ${ }^{19}$ Em sua obra, defende a autoaplicabilidade das normas do art. 226 da CRFB e a aplicação analógica dos efeitos jurídicos da união estável:

"A ausência de lei que regulamente essas uniões não é impedimento para sua existência, porque as normas do art. 226 são autoaplicáveis, independentemente de regulamentação. As uniões homossexuais são constitucionalmente protegidas enquanto tais, com sua natureza própria. Como a legislação ainda não disciplinou seus efeitos jurídicos, como fez com a união estável, as regras desta podem ser aplicáveis àquelas, por analogia (art. $4^{\circ}$ da Lei de Introdução ao Código Civil), em virtude de ser a entidade familiar com maior aproximação de estrutura, nomeadamente quanto às relações pessoais de lealdade, respeito e assistência, alimentos, filhos, adoção, regime de bens e impedimentos" ${ }^{\prime 20}$.

\footnotetext{
${ }^{17}$ VARGAS, Fábio de Oliveira. União Homoafetiva: Direito Sucessório e Novos Direitos p. 48

${ }^{18}$ DIAS, Maria Berenice. Manual de Direito das Famílias, p.198

${ }^{19}$ LÔBO, Paulo Luiz Netto. Direito Civil: Famílias. $4^{\mathrm{a}}$ Edição, 2011. São Paulo: Saraiva. p. 90

${ }^{20}$ Ibid., pp. 90/91.
} 
O dispositivo constitucional em questão privilegia o casamento em detrimento da união estável ${ }^{21}$ na medida em que determina que a lei deverá facilitar a conversão em casamento. Dessa forma, cria-se a impressão de que há uma hierarquia entre os dois institutos. É o que se compreende da lição de Fábio de Oliveira Vargas:

"No mesmo artigo, $\$ 3^{\circ}$ (art. 226), a Lei Magna determina que se facilite a conversão da união estável em casamento, numa postura reveladora de que, mesmo que a união estável também receba proteção como entidade familiar, seria melhor que fosse convertida em casamento" 22 .

Ainda nesse diapasão, é firme a jurisprudência do Superior Tribunal de Justiça no sentido de que não há no Código Civil de 2002 uma vedação implícita ao casamento homoafetivo:

"Os arts. 1.514, 1.521, 1.523, 1.535 e 1.565, todos, do Código Civil de 2002, não vedam expressamente o casamento entre pessoas do mesmo sexo, e não há como se enxergar uma vedação implícita ao casamento homoafetivo sem afronta a caros princípios constitucionais, como o da igualdade, o da não discriminação, o da dignidade da pessoa humana e os do pluralismo e livre planejamento familiar"23.

Diante da inexistência de lei que sequer mencionasse a união entre pessoas do mesmo sexo, a Lei $\mathrm{n}^{\mathbf{0}} 11.340$ de 07 de agosto de 2006, mais conhecida como Lei Maria da Penha inovou ao dispor no parágrafo único do art. $5^{\mathbf{0}^{24}}$ que "as relações pessoais enunciadas no presente artigo independem de orientação sexual". No destaque de Fábio de Oliveira Vargas:

"Embora tenha se restringido apenas à possibilidade de proteção do casal formado por mulheres, a doutrina já se posiciona no sentido da aplicabilidade da

\footnotetext{
${ }^{21}$ LIMA, Wládia Carvalho de Maracaba Calheiros de. Casamento Homossexual sob a Perspectiva da Mutação Constitucional. Revista Jurídica Consulex, Ano XV, n 339, 1 de março de 2011, p. 22

${ }^{22}$ VARGAS, Fábio de Oliveira. União Homoafetiva: Direito Sucessório e Novos Direitos, p.46.

${ }^{23}$ STJ, Resp. n. 1.183.378 - RS (2010/0036663-8) Rel. Ministro Luis Felipe Salomão, Brasília, 25 de out. de 2011.

${ }^{24}$ Art. 5- Para os efeitos desta Lei, configura violência doméstica e familiar contra a mulher qualquer ação ou omissão baseada no gênero que lhe cause morte, lesão, sofrimento físico, sexual ou psicológico e dano moral ou patrimonial: I - no âmbito da unidade doméstica, compreendida como o espaço de convívio permanente de pessoas, com ou sem vínculo familiar, inclusive as esporadicamente agregadas; II - no âmbito da família, compreendida como a comunidade formada por indivíduos que são ou se consideram aparentados, unidos por laços naturais, por afinidade ou por vontade expressa; III - em qualquer relação íntima de afeto, na qual o agressor conviva ou tenha convivido com a ofendida, independentemente de coabitação. Parágrafo único. As relações pessoais enunciadas neste artigo independem de orientação sexual.
} 
referida lei também aos casais homossexuais masculinos, apontando para o fato de que a Lei Maria da Penha é o primeiro instrumento legal que reconhece expressamente a existência da família fundada na homoafetividade" ${ }^{25}$.

\subsection{Omissão do Poder Legislativo}

É nítida a inexistência de lei que regule as relações entre pessoas do mesmo sexo, apesar destas provocarem efeitos jurídicos tanto na seara do direito de família quanto no direito das sucessões.

A omissão do poder legislativo é criticada pela doutrina, que atribui como causa o receio do legislador em perder votos, além do excesso de conservadorismo. Apresentar projetos de lei que defendam interesses de uma minoria pode não ser tão vantajoso politicamente, desagradando o eleitorado. A argumentação encontra respaldo na doutrina de Maria Berenice Dias:

"O repúdio social a segmentos marginalizados e excluídos acaba intimidando o legislador, que tem enorme resistência em chancelar leis que visem a proteger a quem a sociedade rejeita. Por puro preconceito, não aprova leis voltadas a minorias alvo da discriminação. Sequer aprecia projetos que possam desagradar o eleitorado e colocar em risco sua reeleição. A proposta de emenda constitucional, para inserir entre os objetivos fundamentais do Estado (CF $\left.3^{\circ}, \mathrm{IV}\right)$ de promover o bem de todos sem preconceito de orientação sexual (PEC 139/95), e o projeto de parceria civil (PL 1.151/95) são exemplos perfeitos desse preconceito: vagam pelo Congresso Nacional há mais de 10 anos. Atualmente, luta para ser aprovado no Congresso Nacional o PLC 122/06, que objetiva criminalizar a homofobia" ${ }^{26}$.

Considerando a falta de segurança jurídica nas uniões homoafetivas, o Projeto de Lei $n^{\circ} 1.151$, de 1995 de autoria da então Deputada Federal Marta Suplicy propôs a regulamentação da união civil entre pessoas do mesmo sexo. O Projeto de Lei limitou-se a tutelar questões patrimoniais ligadas ao direito das sucessões e propriedade, conforme dispõe seu artigo $1^{\mathrm{o}}$ :

"Art. $1^{\circ}$ - É assegurado a duas pessoas do mesmo sexo o reconhecimento de sua união civil, visando a proteção dos direitos à propriedade, à sucessão e dos demais assegurados nesta Lei".

\footnotetext{
${ }^{25}$ VARGAS, Fábio de Oliveira. União Homoafetiva: Direito Sucessório e Novos Direitos, p.95.

${ }^{26}$ DIAS, Maria Berenice, Manual de Direito das Famílias, p.201.
} 
No destaque de Maria Berenice Dias, apesar de serem objetivos fundamentais da República, uma sociedade livre e justa, que deve promover o bem de todos sem preconceito de origem, raça, sexo, cor, idade ou qualquer outra forma de discriminação, "tais preceitos não parecem ser aplicáveis para gays, lésbicas, bissexuais, travestis e transexuais"27. Condena ainda o "covarde silêncio" do legislador que só alimenta o preconceito às minorias, e cita mais uma vez o Projeto de Lei $\mathrm{n}^{\circ} 1.151$, que como tantos outros não foram apreciados pelas casas legislativas, seja por falta de interesse ou preconceito:

"Basta Lembrar que data de ano de 1995 o primeiro projeto de lei que, tal qual um punhado de tantos outros, vagaram pelas casas legislativas sem nunca terem, sido levados à votação. A maioria foi arquivada. Atualmente existem 16 projetos em tramitação, sem que se vislumbre a possibilidade de serem aprovados. Nem mesmo o que criminaliza a homofobia. A única referência se encontra na Lei Maria da Penha, que conceitua família como relação íntima de afeto, independente da orientação sexual" ${ }^{28}$.

A omissão e a indiferença legislativa atentam contra a dignidade da pessoa humana, pois a homossexualidade é uma condição e os indivíduos devem ser respeitados e ter seus direitos igualmente garantidos independentemente de sua cor, gênero, idade, religião e orientação sexual. Além do mais "a omissão legal leva à resistência nos juízes de reconhecer juridicidade às uniões homossexuais" ${ }^{\prime 29}$.

$\mathrm{Na}$ ausência de previsão legal, doutrina e jurisprudência se adiantam e procuram tutelar direitos decorrentes da união homoafetiva. Isso ocorre porque o magistrado não pode negar a prestação jurisdicional sob a alegação de que não há previsão legal. Não se pode confundir carência legislativa com inexistência de direito ${ }^{30}$. Na esteira da melhor doutrina:

"O julgador não se exime de sentenciar alegando lacuna ou obscuridade da lei. Não se pode pronunciar com um non liquet (não há lei), abstendo-se de julgar

\footnotetext{
27 Id. A Consagração Constitucional da Homoafetividade. Revista Magister de Direito Civil e Processual Civil, v. 42, maio/junho 2011, p. 95

${ }^{28}$ DIAS, Maria Berenice. A Consagração Constitucional da Homoafetividade. Revista Magister de Direito Civil e Processual Civil, v. 42, maio/junho 2011, p. 95

${ }_{29}$ Id. Manual de Direitos das Famílias, p. 201.

${ }^{30}$ Ibid., p. 203.
} 
alegando que não encontrou na lei solução para o litígio. A denegação de justiça agride direitos fundamentais" ${ }^{31}$.

Ademais, de acordo com o art. $4^{\circ}$ da Lei de Introdução às normas do Direito Brasileiro (LICC), quando a lei for omissa, o juiz decidirá o caso de acordo com a analogia, os costumes e os princípios gerais de direito. No mesmo sentido, reza o art. 126 do Código de Processo Civil que o juiz não poderá se eximir de sentenciar ou despachar alegando lacuna ou obscuridade da lei, devendo também em caso de ausência de normas legais recorrer à analogia, aos costumes e aos princípios gerais de direito.

Recentemente, a jurisprudência, ainda que não uniforme, evoluiu e passou a atribuir status de entidade familiar às uniões homoafetivas em detrimento no mero reconhecimento da sociedade de fato. $\mathrm{O}$ entendimento do judiciário apenas foi consolidado com o julgamento da ADPF $\mathrm{n}^{\mathrm{o}} 132 \mathrm{e}$ da ADI n 4.277 pelo STF, que interpretando o art. 1.723 do Código Civil de 2002 de maneira ampla, reconheceu a união homoafetiva como entidade familiar.

O fato é que o direito não pode continuar estático e ignorar o relacionamento entre pessoas no mesmo sexo. A decisão do Supremo, embora para alguns considerada ativista, foi necessária diante da inércia legislativa:

"No caso específico do julgamento da ADPF 132 e da ADI 4.277 o eventual ativismo judicial se justifica pela absoluta omissão e indolência - para não dizer acovardamento - do Legislativo em relação às questões concernentes à homoafetividade. Basta relembrar que existem, em tramitação, projetos de lei que versam sobre as uniões homoafetivas de meados da década de $90^{132}$.

Por sua vez, o Superior Tribunal de Justiça, no julgamento do Recurso Especial $n^{\circ} 1.183 .378$, ressaltou o papel contramajoritário e

\footnotetext{
31 Ibid..

${ }^{32}$ RABELO, César Leandro de Almeida; VIEGAS Cláudia Mara de Almeida Rabelo; POLI, Leonardo Macedo. A Inclusão dos Excluídos: a Regulamentação Jurisdicional para a Família Homoafetiva e o Ativismo Judicial. Revista Direito das Famílias e Sucessões $\mathrm{n}^{\mathbf{0}} 27$ - AbrMaio/2012- Porto Alegre: Magister; Belo Horizonte: IBDFAM, p. 121
} 
protetivo exercido pelo Poder Judiciário que visa salvaguardar minorias vulneráveis.

"Não obstante a omissão legislativa sobre o tema, a maioria, mediante seus representantes eleitos, não poderia mesmo "democraticamente" decretar a perda de direitos civis da minoria pela qual eventualmente nutre alguma aversão. Nesse cenário, em regra é o Poder Judiciário - e não o Legislativo - que exerce um papel contramajoritário e protetivo de especialíssima importância, exatamente por não ser compromissado com as maiorias votantes, mas apenas com a lei e com a Constituição, sempre em vista a proteção dos direitos humanos fundamentais, sejam eles das minorias, sejam das maiorias. Dessa forma, ao contrário do que pensam os críticos, a democracia se fortalece, porquanto esta se reafirma como forma de governo, não das maiorias ocasionais, mas de todos.

Enquanto o Congresso Nacional, no caso brasileiro, não assume explicitamente, sua coparticipação nesse processo constitucional de defesa e proteção dos socialmente vulneráveis, não pode o Poder Judiciário demitir-se desse mister, sob pena de aceitação tácita de um Estado que somente é "democrático"formalmente, sem que tal predicativo resista a uma mínima investigação acerca da universalização dos direitos civis" ${ }^{33}$.

A atuação contramajoritária da Suprema Corte, de acordo com Luis Roberto Barroso e Eduardo Mendonça, se dá no momento em que o STF atende as "demandas sociais e anseios políticos que não foram satisfeitos a tempo e a hora pelo Congresso Nacional":

(...) em nome da Constituição, da proteção das regras do jogo democrático e dos direitos fundamentais cabe à ela (Suprema Corte) a atribuição de declarar a inconstitucionalidade de leis (i.e., de decisões majoritárias tomadas pelo Congresso) e de atos do Poder Executivo (cujo chefe foi eleito pela maioria absoluta dos cidadãos). Vale dizer: agentes públicos não eleitos, como juízes e ministros do STF, podem sobrepor a sua razão à dos tradicionais representantes da política majoritária. Daí o termo contramajoritário ${ }^{34}$.

Apesar de fundamental na concretização dos direitos da família homoafetiva, a atuação do judiciário decorrente da falta de previsão legislativa não traz segurança jurídica suficiente. Ainda há muita incerteza quanto aos efeitos resultantes da união homoafetiva. Parte da doutrina sustenta a necessidade de uma emenda constitucional para regulamentar a união estável homoafetiva ou até mesmo o casamento entre pessoas do

\footnotetext{
33 STJ, Quarta turma. Resp. n. 1.183.378 - RS (2010/0036663-8) Relator Ministro Luis Felipe Salomão, Brasília, julgado em 25 de out. de 2011.

${ }^{34}$ BARROSO, Luis Roberto; MENDONÇA, Eduardo. O STF entre seus papéis contramajoritário $e$ representativo. Artigo publicado em 04/01/2013. Disponível em http://www.osconstitucionalistas.com.br/o-stf-entre-seus-papeis-contramajoritario-erepresentativo. Acesso em 03/06/2013
} 
mesmo sexo. "Dessa forma, o legislador estaria aplicando efetivamente o princípio da igualdade e da liberdade versados como basilares do Estado Democrático de Direito" ${ }^{\prime 35}$.

Ante o exposto, conclui-se pela necessidade de se legislar acerca do assunto, equiparando a união homoafetiva à união entre o homem e a mulher para que possam ser concedidos os mesmos direitos, tais como a união civil, que consequentemente possibilita a sucessão do cônjuge ou companheiro e até mesmo o direito à adoção por casais do mesmo sexo.

35 RABELO, César Leandro de Almeida; VIEGAS Cláudia Mara de Almeida Rabelo; POLI, Leonardo Macedo. A Inclusão dos Excluídos: a Regulamentação Jurisdicional para a Família Homoafetiva e o Ativismo Judicial. Revista Direito das Famílias e Sucessões $n^{\mathbf{o}} 27$ - AbrMaio/2012- Porto Alegre: Magister; Belo Horizonte: IBDFAM, p. 116 


\section{O Direito sucessório do cônjuge e do companheiro}

\subsection{Sociedade de fato}

A sociedade de fato, instituto do direito obrigacional, se caracteriza pelo simples acordo de vontade entre as partes e falta de formalidade. Ainda que exista contrato, este não possui registro. Entretanto, efeitos jurídicos patrimoniais são reconhecidos ${ }^{36}$.

De acordo com o art. 981 do Código Civil de 2002, na sociedade de fato os partícipes contribuem reciprocamente com bens e serviços para o exercício de atividade econômica e a partilha, entre si, dos resultados. ${ }^{37}$

O instituto da sociedade de fato era aplicada à união estável entre homem e mulher antes não regulamentada. O Supremo Tribunal Federal utilizou a expressão "concubinos" ao editar a Súmula $380^{38}$. Ressalta-se que a súmula faz menção a necessidade de prova da sociedade de fato como requisito para a partilha.

Com o advento da Constituição de 1988, as uniões de fato entre um homem e uma mulher foram reconhecidas como entidade familiar, com o nome de união estável ${ }^{39}$. Apesar da autoaplicabilidade, os tribunais não empregaram de imediato esse novo direito, aplicando ainda a súmula 380.

"Nada foi alterado, como se não tivesse existido a transformação do que antes era considerado um fato espúrio em uma relação jurídica. Também em matéria sucessória não houve nenhuma evolução. Persistiu a vedação de conceder herança ao companheiro sobrevivente e a negativa de assegurar direito real de habitação ou usufruto de parte dos bens. Tímidas as mudanças ocorridas e as raras exceções foram decisões isoladas" 40 .

\footnotetext{
${ }^{36}$ VARGAS, Fábio de Oliveira. União Homoafetiva: Direito Sucessório e Novos Direitos, p. 32.

37 Art. 981. Celebram contrato de sociedade as pessoas que reciprocamente se obrigam a contribuir, com bens ou serviços, para o exercício de atividade econômica e a partilha, entre si, dos resultados. Parágrafo único. A atividade pode restringir-se à realização de um ou mais negócios determinados.

${ }^{38}$ STF, Súmula 380. Comprovada a existência de sociedade de fato entre os concubinos, é cabível a sua dissolução judicial, com a partilha do patrimônio adquirido pelo esforço comum.

${ }^{39}$ DIAS, Maria Berenice. Manual de Direito das Famílias. p. 168

${ }^{40}$ Ibid.
} 
Mesmo após a regulamentação da união estável entre homem e mulher e o esquecimento da aplicação da sociedade de fato, tal instituto votou a ser utilizado, desta vez, em relação à união entre pessoas do mesmo sexo, situação essa que demonstra nítido retrocesso. Nesse sentido, Fábio de Oliveira Vargas:

"Comparar a união homossexual à sociedade de fato com base no art. 1.369 do CC/16 ou no art. 981 do CC/02, foi a forma encontrada pelos operadores do Direito para tutelar os interesses dos participantes desta modalidade de relacionamento amoroso: a união hoje denominada estável" ${ }^{41}$.

A aplicação da sociedade de fato na união entre pessoas do mesmo sexo não é suficiente, tendo em vista que não leva em consideração o afeto presente nas relações amorosas. O instituto, que pertence ao direito obrigacional, não dá o status que a união homossexual merece receber: de entidade familiar.

Maria Berenice Dias critica a analogia atribuída à união homoafetiva e a sociedade de fato, considerando-a nitidamente preconceituosa, pois transforma a natureza do vínculo afetivo em obrigação negocial. Segunda a autora, a inserção da união entre pessoas do mesmo sexo no direito obrigacional rompe com a proteção do direito das famílias às uniões desse tipo, o que acaba por afastar os direitos sucessórios ${ }^{42}$. (Grifo nosso)

Nas relações heterossexuais, o fim da união traz o direito a pleitear alimentos, além da partilha dos bens. Nos casos de falecimento, o sobrevivente concorre com os demais herdeiros e lhe é assegurado o direito real de habitação, ou lhe é entregue a herança ${ }^{43}$. Em ambos os casos, a vara de família é competente para julgar a demanda, diferentemente das relações homossexuais tratadas como sociedade de fato, onde a distribuição é feita nas varas cíveis.

\footnotetext{
${ }^{41}$ VARGAS, Fábio de Oliveira. União Homoafetiva: Direito Sucessório e Novos Direitos, p. 33

${ }^{42}$ DIAS, Maria Berenice. Manual de Direito das Famílias, p. 201

${ }^{43} \mathrm{Ibid}$
} 
Ainda nesse diapasão, Fábio de Oliveira Vargas faz ressalvas à aplicação da sociedade de fato quanto ao direito das sucessões:

"[...] em sede de sociedade de fato, não se discute direito sucessório propriamente. Ocorre apenas a partilha do patrimônio comum, o que também se daria na hipótese de dissolução da sociedade por vontade das partes, por exemplo. E neste caso, o "sócio", para receber a pare que lhe caberia, deveria fazer prova de quanto contribuiu na aquisição do patrimônio societário" ${ }^{44}$.

Como visto, a aplicação do instituto da sociedade de fato nas relações homoafetivas exclui o direito sucessório. Ao "sócio" caberá apenas a divisão de "lucros" e somente mediante comprovação de sua efetiva colaboração.

"Mesmo comprovada a convivência duradoura, pública e contínua, a tendência ainda é reconhecida somente a existência de uma sociedade de fato, sob o fundamento de ser impertinente qualquer indagação sobre a vida íntima dos sócios. Ao parceiro, no máximo é deferida a metade - às vezes nem isso - do patrimônio adquirido durante a vida em comum, e, ainda assim, mediante a prova de efetiva colaboração" 45 .

Após o "sócio" receber a parte que lhe cabe, os demais herdeiros são chamados à sucessão. Na falta de herdeiros necessários, parentes de até $4^{\circ}$ grau poderão receber parte da herança. Maria Berenice Dias atenta para a flagrante injustiça e possível enriquecimento sem causa dessa situação, pois pessoas que não conviviam e não tinham contato frequente com o de cujus repentinamente enriquecem as suas custas:

"[...] se o fim do relacionamento decorre da morte de um dos parceiros, a injustiça dessa solução é flagrante. Com a separação, cada um recebe metade do patrimônio amealhado durante o período de vida em comum. Mas, na hipótese de falecimento, outorgar somente a meação dos bens ao sobrevivente dá ensejo ao enriquecimento sem causa dos parentes que não são herdeiros necessários. Ao menos por metade é infringido o cânone que tanto repugna à justiça, pois se faz meia justiça quando se entrega metade do acervo hereditário, por exemplo, aos irmãos, tios, sobrinhos ou primos do companheiro falecido. Não se pode negar a ocorrência de injustificado proveito dos familiares - que normalmente hostilizavam a opção sexual do de cujus - em detrimento de quem dedicou a vida ao companheiro, ajudou a amealhar o patrimônio e se vê sozinho, abandonado e sem nada"46.

\footnotetext{
${ }^{44}$ VARGAS, Fábio de Oliveira. Op.cit., p. 34.

${ }^{45}$ DIAS, Maria Berenice. Manual de Direito das Famílias, p 201

${ }^{46}$ Ibid., p 202.
} 
Aos poucos, a jurisprudência foi atribuindo status de entidade familiar às uniões homoafetivas e não mais reconhecem apenas a existência de mera sociedade de fato. Devido à grande contribuição do IBDFAM Instituto Brasileiro de Direito de Família - a união homoafetiva migrou para o conceito de família ${ }^{47}$. Ademais, após o julgamento da ADP 132 e ADI 4.277 que a atribuiu às uniões entre pessoas do mesmo sexo status de família, encontramos apenas decisões isoladas que continuam empregando o instituto da sociedade de fato.

Exemplo de tal superação da aplicação da sociedade de fato na união homoafetiva pode ser encontrado na recente decisão o Tribunal de Justiça do Estado do Rio de Janeiro que entendeu que embora as partes tenham optado pela sociedade de fato, não é possível fazer distinção entre casais homossexuais e heterossexuais. O tribunal julgou desprovido o recurso em razão de improcedência do pedido na ação de reconhecimento e dissolução de sociedade de fato com fundamento no art. 557 do $\mathrm{CPC}^{48}$, levando em consideração os precedentes do STJ e STF sobre a matéria em questão.

AGRAVO INTERNO INTERPOSTO PELO AUTOR. APELAÇÃO DO AUTOR DESPROVIDA. DECISÃO EM CONSONÂNCIA COM A JURISPRUDÊNCIA PREDOMINANTE NESTA CORTE. AÇÃO DE RECONHECIMENTO E DISSOLUÇÃO DE SOCIEDADE DE FATO. IMPROCEDÊNCIA DO PEDIDO. MANUTENÇÃO DA SENTENÇA. Embora tal discrição seja critério das partes envolvidas, é preciso que a relação seja comprovada por todas as formas admitidas no direito, não podendo ser alterada a definição do que se entende por "união estável" no caso de pessoas do mesmo sexo, pois se estaria, novamente, voltando a fazer distinção entre casais heterossexuais dos homossexuais, quando, na verdade, o que se quis, foi que todos recebessem igual proteção tanto das leis quanto do sistema político-jurídico instituído pela Constituição. DESPROVIMENTO DO RECURSO. ${ }^{49}$

\footnotetext{
47 DIAS, Maria Berenice. A Consagração Constitucional da Homoafetividade. Revista Magister de Direito Civil e Processual Civil, p. 95

48 Art. 557. O relator negará seguimento a recurso manifestamente inadmissível, improcedente, prejudicado ou em confronto com súmula ou com jurisprudência dominante do respectivo tribunal, do Supremo Tribunal Federal, ou de Tribunal Superior

49 TJRJ - Décima Oitava Câmara Cível - Apelação n 0366919-12.2008.8.19.0001 - Relator Jorge Luiz Habib, Rio de Janeiro, 11 de set. de 2012.
} 


\title{
2.2. Casamento
}

Durante muito tempo, doutrina e jurisprudência ainda resistiram em conceder às uniões homoafetivas os mesmos efeitos jurídicos do casamento. Parte da doutrina entendia que o casamento entre pessoas do mesmo sexo não é nulo e nem anulável, mas um negócio jurídico inexistente ${ }^{50}$. A adoção dessa posição impossibilita, consequentemente, a atribuição aos casais homoafetivos de direitos sucessórios similares aos dos cônjuges.

O matrimônio no Brasil está na maioria das vezes ligado à religião. Muitas vezes, é dada maior importância ao casamento no religioso em detrimento do casamento civil. Prova disto é o $\S 2^{\circ}$ do art. 226 da CRFB/88 que reconhece efeitos civis ao casamento religioso. O liame entre casamento e religião pode dificultar ainda mais a aceitação da união homoafetiva, uma vez que a sociedade brasileira é considerada religiosa de modo geral, apesar de o Brasil ser um Estado laico. As religiões prezam pela tradição e um modelo conservador de família, ou seja, heterossexual.

Entretanto, muitos autores, dentre eles Maria Berenice Dias, apontam a superação do casamento conservador, patriarcal e heterossexual.

\begin{abstract}
"Não há como fugir da analogia com as demais relações que têm o afeto por causa, e, assim, reconhecer a existência de uma entidade familiar à semelhança do casamento e da união estável. O óbice constitucional, estabelecendo a distinção de sexos ao definir a união estável, não impede o uso dessa forma integrativa de um fato existente e não regulamentado no sistema jurídico. A identidade sexual não serve de justificativa para que seja buscado qualquer outro ramo do direito que não o direito das famílias" ${ }^{51}$.
\end{abstract}

\subsubsection{Direitos Sucessórios no Casamento - A Controversa Sucessão do Cônjuge}

O Código Civil de 1916 não atribuiu ao cônjuge o status de herdeiro necessário em propriedade plena, sendo-lhe garantido tão somente o

\footnotetext{
${ }^{50}$ VARGAS, Fábio de Oliveira. União Homoafetiva: Direito Sucessório e Novos Direitos, p. 52.

${ }^{51}$ DIAS, Maria Berenice. Manual de Direito das Famílias, p.204.
} 
usufruto vidual $\left(\mathrm{CC} / 16 \text {, art. 1611, } \S 1^{\circ}\right)^{52}$. Segundo Ana Luiza Maia Nevares, o usufruto vidual representou apenas uma pequena contribuição às transformações da família, pois tinha o escopo de conservar o patrimônio dentro do grupo familiar, evitando assim a transmissão dos bens recebidos por ocasião do falecimento do consorte à nova família, formada por segundas núpcias, em detrimento dos filhos do casamento anterior ${ }^{53}$.

A atribuição do usufruto vidual é destinada ao cônjuge quando não lhe toca a plena propriedade da herança e apenas se seu regime de bens do matrimônio for diverso da comunhão universal ${ }^{54}$.

Com o advento do Código Civil de 2002, o cônjuge além de meeiro passou a ser herdeiro necessário. O progresso do novo Código Civil foi comemorado pela doutrina devido à maior proteção ao cônjuge supérstite, que foi incluído na legítima.

"O novo Código Civil, em vigor desde 11 de janeiro de 2003, inovou quanto à sucessão do cônjuge. Tendo em vista oferecer maior proteção ao cônjuge sobrevivente, ergueu-o ao patamar de herdeiro necessário, em concorrência com descendentes e ascendentes, condição hoje negada ao companheiro, seja ele homo ou heterossexual" ${ }^{55}$.

A inserção do cônjuge no rol dos herdeiros necessários pelo Código Civil de 2002 ocorreu porque "o cônjuge é o único componente estável e essencial, uma vez que os filhos, em um determinado momento, irão se desprender daquela entidade, formando sua própria comunidade familiar" ${ }^{56}$.

Em razão do princípio de Saisine, ficção jurídica na qual após a morte do autor da herança os herdeiros recebem desde logo a posse e a propriedade, com a abertura da sucessão o cônjuge é constituído em

\footnotetext{
${ }^{52}$ NEVARES, Ana Luiza Maia. A Tutela Sucessória do Cônjuge e do Companheiro na Legalidade Constitucional. Rio de Janeiro: Renovar, 2004, p. 73.

${ }^{53}$ Ibid. p.74.

${ }^{54}$ Ibid. p. 94.

${ }^{55}$ VARGAS, Fábio de Oliveira. União Homoafetiva: Direito Sucessório e Novos Direitos, p.49.

${ }^{56}$ L. MEZZANOTTE, La sucessione anomala del coniuge, cit. p 16. In Ana Luiza Nevares, A Tutela Sucessória do Cônjuge e do Companheiro na Legalidade Constitucional. Rio de Janeiro: Renovar, 2004, p.74
} 
herdeiro necessário e poderá exercer todas as ações de defesa da herança, mesmo não estando na posse de fato.

Sendo o cônjuge herdeiro necessário, faz jus à legítima e receberá obrigatoriamente parte da herança. O herdeiro necessário não participará da sucessão apenas se for considerado indigno, se for deserdado ou se renunciar a herança (Art. 1.845 c/c Art. 1846, CC/2002).

O cônjuge sobrevivo não precisa fazer prova do esforço comum na construção do patrimônio, diferentemente do companheiro. Para que possa receber sua parte da herança basta a apresentação da certidão de casamento e da certidão de óbito do autor da herança ${ }^{57}$.

No que concerne ao regime de bens, o Código Civil de 2002 prevê quatro possibilidades: comunhão parcial (artigo 1.658), comunhão universal de bens (artigo 1.667 do CC), separação de bens - voluntária (artigo 1.687) ou obrigatória (artigo 1.641) e participação final nos aquestos (artigo 1.672).

Com o advento da Lei 6.515/77 (Lei do Divórcio), na ausência de convenção, passou a vigorar quanto aos bens entre os cônjuges o regime da comunhão parcial (Art. 1.640 do CC), consideradas as exceções legais previstas no art. 1.659 do CC/02. O mesmo se dá em relação aos companheiros (Art. 1725 do CC).

No que tange à sucessão no casamento, o art. 1829 do Código Civil de 2002 dispõe que o cônjuge sobrevivente ocupa o terceiro lugar na linha de sucessão, concorrendo com os descendentes e os ascendentes do de cujus. Somente na ausência de herdeiros das duas primeiras classes, a sucessão lhe será deferida por inteiro (CC/02, arts. 1.829 e 1.838), seja qual

\footnotetext{
${ }^{57}$ VARGAS, Fabio de Oliveira. União Homoafetiva: Direito Sucessório e Novos Direitos, p. 50
} 
for o regime matrimonial, comunitário, ou não, de separação pactuada, ou obrigatória, ou, ainda, da participação final nos aquestos ${ }^{58}$.

Reza o Art. 1.829, I que na sucessão legítima o cônjuge concorre com os descendentes salvo se: casado este com o falecido no regime da comunhão universal, ou no da separação obrigatória de bens (art. 1.640, parágrafo único); ou se, no regime da comunhão parcial, o autor da herança não houver deixado bens particulares. Nesses casos, o cônjuge sobrevivente não é herdeiro. No mesmo sentido, Fábio de Oliveira Vargas expõe:

\footnotetext{
"Vale ressaltar que o regime de bens em vigor durante o casamento apenas interfere na herança do cônjuge quando este concorre com descendentes do falecido. Neste caso, só receberá herança quem tiver sido casado pelos regimes da comunhão parcial, da participação final nos aquestos, ou do regime da separação total convencional - hipóteses em que a herança será tirada aos bens particulares eventualmente deixados pelo de cujus $^{\prime \prime 59}$.
}

Nessa linha, vale a pena conferir o voto da Ministra Nancy Andrighi, relatora do Recurso Especial no 992.749 - MS (2007/0229597-9) ${ }^{60}$ interposto sob alegação de ofensa aos arts. 535 do CPC; 884, 1.639, §§ $1^{\circ} \mathrm{e}$ $2^{\circ}, 1.687$, do $\mathrm{CC} / 02$. A ministra destaca a existência de três correntes que interpretam o art. 1.829, I de maneira completamente diversa, devido à ambiguidade de sua redação. Em seu voto, que é praticamente uma aula referente à concorrência do cônjuge e descendentes na sucessão, a Ministra elaborou quadros ${ }^{61}$ para alcançar maior compreensão. Tais quadros partem do pressuposto de que o de cujus deixou bens particulares e descendentes.

De acordo com o julgado, a primeira corrente se origina a do Enunciado 270, da III Jornada de Direito Civil, organizada pelo Conselho da Justiça Federal, que estatui:

\footnotetext{
${ }^{58}$ GOMES, Orlando. Sucessões. 14. ed. rev., atual e ampl. Rio de Janeiro: Forense, 2007. p. 64

${ }^{59}$ VARGAS, Fabio de Oliveira. União Homoafetiva: Direito Sucessório e Novos Direitos, p. 51.

${ }^{60}$ STJ - Terceira Turma - Recurso Especial no 992.749 - MS (2007/0229597-9) Relatora Ministra Nancy Andrighi, Brasília, 01 de dez. de 2009.

${ }^{61}$ Quadros demonstrativos das regras gerais de sucessão legítima elaborados pela Ministra Nancy Andrighi, relatora do Recurso Especial nº 992.749 - MS (2007/0229597-9).
} 
"Enunciado 270.

Art. 1.829: O art. 1.829, inc. I, só assegura ao cônjuge sobrevivente o direito de concorrência com os descendentes do autor da herança quando casados no regime da separação convencional de bens ou, se casados nos regimes da comunhão parcial ou participação final nos aquestos, o falecido possuísse bens particulares, hipóteses em que a concorrência se restringe a tais bens, devendo os bens comuns (meação) ser partilhados exclusivamente entre os descendentes".

Segundo tal concepção, o quadro demonstrativo ficaria disposto da seguinte maneira:

\begin{tabular}{|c|c|c|c|}
\hline Regimes & Meação & $\begin{array}{c}\text { Cônjuge herda } \\
\text { bens particulares? }\end{array}$ & $\begin{array}{c}\text { Cônjuge herda } \\
\text { bens comuns? }\end{array}$ \\
\hline Comunhão universal & Sim & Não & Não \\
\hline Comunhão parcial & Sim & $\begin{array}{c}\text { Sim, em concurso } \\
\text { com os descendentes }\end{array}$ & Não \\
\hline Separação obrigatória & Não definido & Não & Não \\
\hline $\begin{array}{c}\text { Separação } \\
\text { convencional }\end{array}$ & $\begin{array}{c}\text { Não, em } \\
\text { princípio }\end{array}$ & $\begin{array}{c}\text { Sim, em concurso } \\
\text { com os descendentes }\end{array}$ & $\begin{array}{c}\text { Não há, em } \\
\text { princípio, bens } \\
\text { comuns }\end{array}$ \\
\hline
\end{tabular}

Por sua vez, conforme a segunda corrente (majoritária), caso o autor da herança tenha deixado bens particulares, "o cônjuge herda, nas proporções fixadas pela Lei (arts. 1.830, 1.832 e 1.837), não apenas os bens particulares, mas todo o acervo hereditário". (grifo do autor)

\begin{tabular}{|c|c|c|c|}
\hline Regimes & Meação & $\begin{array}{c}\text { Cônjuge herda } \\
\text { bens particulares? }\end{array}$ & $\begin{array}{c}\text { Cônjuge herda } \\
\text { bens comuns? }\end{array}$ \\
\hline Comunhão universal & Sim & Não & Não \\
\hline Comunhão parcial & Sim & $\begin{array}{c}\text { Sim, em concurso } \\
\text { com os } \\
\text { descendentes }\end{array}$ & $\begin{array}{c}\text { Sim, em concurso } \\
\text { com os } \\
\text { descendentes }\end{array}$ \\
\hline Separação obrigatória & Não definido & Não & Não \\
\hline $\begin{array}{c}\text { Separação } \\
\text { convencional }\end{array}$ & $\begin{array}{c}\text { Não, em } \\
\text { princípio }\end{array}$ & $\begin{array}{c}\text { Sim, em concurso } \\
\text { com os } \\
\text { descendentes }\end{array}$ & $\begin{array}{c}\text { Sim, se os houver, } \\
\text { em concurso com os } \\
\text { descendentes }\end{array}$ \\
\hline
\end{tabular}

Finalmente, a terceira corrente liderada por Maria Berenice Dias ${ }^{62}$, defende que só há sucessão caso o cônjuge casado pelo regime de comunhão parcial não tenha deixado bens particulares, entretanto, quanto

62 DIAS, Maria Berenice. Ponto Final. Disponível em <http://www.mariaberenicedias.com.br/uploads/2_-_ponto_final.pdf>. Acesso em 04 de junho de 2013. 
aos bens comuns, cônjuge concorre com os descendentes. No que tange à separação de bens, na obrigatória o cônjuge não herda bens particulares nem comuns. Já na convencional, há concorrência com os descendentes.

\begin{tabular}{|c|c|c|c|}
\hline Regimes & Meação & $\begin{array}{c}\text { Cônjuge herda } \\
\text { bens particulares? }\end{array}$ & $\begin{array}{c}\text { Cônjuge herda } \\
\text { bens comuns? }\end{array}$ \\
\hline Comunhão universal & Sim & Não & Não \\
\hline Comunhão parcial & Sim & $\begin{array}{c}\text { Não há herança do } \\
\text { cônjuge, se houver } \\
\text { bens particulares. }\end{array}$ & $\begin{array}{c}\text { Sim, em concurso } \\
\text { com os } \\
\text { descendentes }\end{array}$ \\
\hline Separação obrigatória & Não definido & Não & Não \\
\hline $\begin{array}{c}\text { Separação } \\
\text { convencional }\end{array}$ & $\begin{array}{c}\text { Não, em } \\
\text { princípio }\end{array}$ & $\begin{array}{c}\text { Sim, em concurso } \\
\text { com os } \\
\text { descendentes }\end{array}$ & $\begin{array}{c}\text { Sim, se os houver, } \\
\text { em concurso com os } \\
\text { descendentes }\end{array}$ \\
\hline
\end{tabular}

Após a análise das correntes expostas acima, no que se refere à comunhão parcial de bens, a Ministra frisou que a vontade das partes deve ser valorizada. Se os cônjuges em vida optaram pelo regime da comunhão parcial, sua escolha deve ser respeitada. Não há sentido que após a morte de um dos consortes o regime de bens outrora escolhido - comunhão parcial se transforme em outro - comunhão universal -, no qual todo o patrimônio adquirido na constância ou anteriormente à união faz parte da meação.

O entendimento das três correntes doutrinárias demonstradas nos quadros acima é diverso da concepção adotada pela Ministra, que as contesta:

"A permanecer a interpretação conferida pela doutrina majoritária de que o cônjuge casado sob o regime da comunhão parcial herda em concorrência com os descendentes, inclusive no tocante aos bens particulares, teremos no Direito das Sucessões, na verdade, a transmutação do regime escolhido em vida -comunhão parcial de bens - nos moldes do Direito Patrimonial de Família, para o da comunhão universal, somente possível de ser celebrado por meio de pacto antenupcial por escritura pública. Não se pode ter após a morte o que não se queria em vida. A adoção do entendimento de que o cônjuge sobrevivente casado pelo regime da comunhão parcial de bens concorre com os descendentes do falecido a todo o acervo hereditário, viola, além do mais, a essência do próprio regime estipulado"63.

A avaliação acerca da sucessão do cônjuge continua. Desta vez aprecia-se a separação de bens pode ser convencional ou legal, sendo que

\footnotetext{
${ }^{63}$ STJ - Terceira Turma - Recurso Especial no 992.749 - MS (2007/0229597-9) Relatora Ministra Nancy Andrighi, Brasília, Julgado em 01 de dezembro de 2009.
} 
esta decorre da lei e aquela decorre da vontade das partes, e se dá por pacto antenupcial lavrado por escritura pública.

Conforme entendimento expressado no Recurso Especial em comento, o regime da separação de bens, salvo previsão diversa no pacto antenupcial, não comporta meação nem concorrência sucessória do cônjuge supérstite. Dessa forma, o cônjuge não é considerado herdeiro em nenhuma das modalidades de separação de bens - legal e convencional e todos os bens deixados pelo de cujus pertencerão aos descendentes.

\begin{abstract}
"Entendimento em sentido diverso, suscitaria clara antinomia entre os arts. 1.829, inc. I, e 1.687, do CC/02, o que geraria uma quebra da unidade sistemática da lei codificada, e provocaria a morte do regime de separação de bens. Por isso, entre uma interpretação que torna ausente de significado o art.1.687 do CC/02, e outra que conjuga e torna complementares os citados dispositivos, não é crível que seja conferida preferência à primeira solução" ${ }^{164}$.
\end{abstract}

Cabe ressaltar que em relação ao regime da comunhão universal não houve alteração, sendo acompanhado o mesmo entendimento previsto nos quadros acima expostos: ao cônjuge sobrevivente cabe apenas a meação, e não a herança.

Ante o exposto, conclui a de acordo com a linha de interpretação da ministra, o quadro demonstrativo se resumiria da seguinte maneira:

\begin{tabular}{|c|c|c|c|}
\hline Regimes & Meação & $\begin{array}{c}\text { Cônjuge herda } \\
\text { bens particulares? }\end{array}$ & $\begin{array}{c}\text { Cônjuge herda } \\
\text { bens comuns? }\end{array}$ \\
\hline Comunhão universal & Sim & Não & Não \\
\hline Comunhão parcial & Sim & Não & $\begin{array}{c}\text { Sim, em concurso } \\
\text { com os } \\
\text { descendentes }\end{array}$ \\
\hline $\begin{array}{c}\text { Separação de bens, } \\
\text { que pode ser legal ou } \\
\text { convencional }\end{array}$ & Não & Não & Não \\
\hline
\end{tabular}

Prosseguindo com a análise dos artigos que compõe o Capítulo I - Da Ordem da Vocação Hereditária - do Título II, Livro V do CC/02, vale ainda destacar o disposto no art. 1.830 do $\mathrm{CC} / 02$, visto como retrógrado e

\footnotetext{
${ }^{64}$ STJ - Terceira Turma - Recurso Especial no 992.749 - MS (2007/0229597-9) Relatora Ministra Nancy Andrighi, Brasília, Julgado em 01 de dezembro de 2009.
} 
alvo de muitas críticas da doutrina civilista, pois faz menção à culpa da separação dos cônjuges. Conforme preceitua o artigo, não é reconhecido direito sucessório ao cônjuge sobrevivente se no momento da abertura da sucessão não estava separado judicialmente ou separado de fato do de cujus há mais de dois anos, salvo prova, neste caso, de que a convivência se tornara impossível sem culpa do sobrevivente.

Entretanto, a tendência é de que essa disposição caia em desuso, tendo em vista que a Emenda Constitucional n ${ }^{\circ} 66$ de 13 de julho de 2010 excluiu a separação judicial do ordenamento jurídico brasileiro. A emenda deu nova redação ao $\S 6^{\circ}$ do art. 226 da Constituição Federal, que dispõe sobre a dissolubilidade do casamento civil pelo divórcio, suprimindo o requisito de prévia separação judicial por mais de 1 (um) ano ou de comprovada separação de fato por mais de 2 (dois) anos ${ }^{65}$.

Em relação ao direito real de habitação, é concedido ao cônjuge sobrevivente caso o imóvel em que reside a família seja o único a inventariar, conforme preceitua o art. 1.831 do Código Civil.

"A condição que se impõe para sua atribuição é tratar-se de imóvel único destinado à residência da família.

(...)

O direito de habitação grava o imóvel enquanto viver o cônjuge supérstite, não restringindo o legislador sua duração ao período de viuvez, como o fazia o texto revogado"66.

Insta salientar que caso o cônjuge sobrevivente receba a herança por inteiro, não cabe direito real de habitação, tendo em vista que o imóvel já faz parte de seu patrimônio.

Por fim, em concorrência com os filhos exclusivos do de cujus, caberá ao cônjuge quinhão igual ao dos que sucederem por cabeça. Sendo filhos comuns, sua quota não pode ser inferior à $25 \%$ da herança. Ao concorrer com ascendente em primeiro grau, caberá ao cônjuge supérstite

\footnotetext{
${ }^{65}$ Disponível em <http://www.planalto.gov.br/ccivil_03/constituicao/Emendas/Emc/emc66.htm>. Acesso em 06 de maio de 2013.

${ }^{66}$ GOMES, Orlando. . Sucessões. 14. ed. rev., atual e ampl. Rio de Janeiro: Forense, 2007. p. 65
} 
um terço da herança. Se houver apenas um ascendente ou se tratar-se de ascendentes de maior grau (avós do de cujus, por exemplo), o cônjuge terá direito à metade da herança. E finalmente, na falta de descendentes ou ascendentes, caberá ao cônjuge sobrevivente a totalidade da herança, diferentemente do que dispõe a lei sobre a sucessão do companheiro.

Como veremos a seguir, o conjunto de regras aplicado ao casamento "não se dá nos mesmos termos para a companheiro heterossexual, muito menos é estendido, ainda que analogicamente, ao companheiro homossexual sobrevivo" ${ }^{\prime 67}$.

\subsubsection{A possibilidade do casamento entre pessoas do mesmo sexo}

O casamento entre pessoas do mesmo sexo é permitido em 14 países: Holanda (2001), Bélgica (2003), Espanha (2005), Canadá (2005), África do Sul (2006), Noruega (2009), Suécia (2009), Portugal (2010), Islândia (2010), Argentina (2010), Dinamarca (2012), Uruguai (2013), Nova Zelândia (2013) e França (2013) ${ }^{68}$.

No Brasil, o legislador, intencionalmente, fez questão de salientar que a diferença de sexos constituí requisito essencial tanto para o

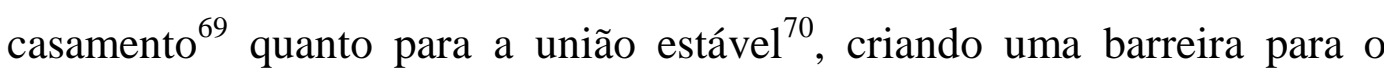
reconhecimento legal da união homoafetiva.

Entretanto, a recente Resolução $\mathrm{n}^{\circ} 175$ do Conselho Nacional de Justiça representou grande avanço no que tange os direitos civis de pares do mesmo sexo que até então não tinham permissão para o casamento civil. A Resolução tornou desnecessário o ajuizamento de demandas no Poder Judiciário pleiteando a união homoafetiva.

\footnotetext{
${ }^{67}$ VARGAS, Fábio de Oliveira. União Homoafetiva: Direito Sucessório e Novos Direitos, p. 51

68 Disponível em <http://g1.globo.com/mundo/noticia/2013/04/conheca-os-14-paises-em-que-ocasamento-gay-foi-aprovado.html>. Acesso em 06 de maio de 2013.

${ }^{69} \mathrm{CC} / 02$. Art. 1.514. O casamento se realiza no momento em que o homem e a mulher manifestam, perante o juiz, a sua vontade de estabelecer vínculo conjugal, e o juiz os declara casados.

${ }^{70} \mathrm{CC} / 02$. Art. 1.723. É reconhecida como entidade familiar a união estável entre o homem e a mulher, configurada na convivência pública, contínua e duradoura e estabelecida com o objetivo de constituição de família
} 
O Conselho Nacional de Justiça presidido pelo Ministro Joaquim Barbosa editou a Resolução $n^{\circ} 175^{71}$ que entrou em vigor na data de sua publicação, 14 de maio de 2013. A resolução dispõe sobre a habilitação, celebração de casamento civil, ou de conversão de união estável em casamento entre pessoas de mesmo sexo.

Considerando o acórdão prolatado pelo STF no julgamento da ADPF 132/RJ e da ADI 4277/DF que reconheceu a inconstitucionalidade de distinção de tratamento legal às uniões estáveis homoafetivas, o julgamento do RESP 1.183.378/RS e tendo em vista que as decisões foram proferidas com eficácia vinculante à administração pública e aos demais órgãos do Poder Judiciário, o Conselho Nacional de Justiça determinou que é vedada a recusa pelas autoridades competentes da habilitação, da celebração de casamento civil ou de conversão de união estável em casamento entre pessoas de mesmo sexo. Caso a medida seja descumprida pela autoridade competente, o respectivo juiz corregedor será imediatamente comunicado para providências cabíveis, que de acordo com o art. 32 da Lei $n^{\circ} 8.935$ de 18 de novembro de $1994^{72}$ podem variar entre as seguintes penas: repreensão, multa, suspensão por noventa dias, prorrogável por mais trinta ou perda da delegação.

Nessa linha, destaca-se a submissão dos Cartórios de Registro Civil à recente Resolução do CNJ:

"É verdade que os denominados Cartórios de Registro Civil das Pessoas Naturais não integram a Administração Direta ou Indireta. Nos termos do artigo 236 da Constituição, os serviços notariais e de registro são exercidos em caráter privado, por delegação do Poder Público. São, dessa forma, particulares em colaboração com o Poder Público, por delegação (descentralização administrativa por delegação). Essa constatação não exclui, contudo, a submissão desses profissionais do Direito à decisões proferidas pelo Judiciário, em especial às dos

\footnotetext{
$71 \quad$ Disponível em $\quad<$ http://www.cnj.jus.br/atos-administrativos/atos-dapresidencia/resolucoespresidencia/24675-resolucao-n-175-de-14-de-maio-de-2013>. Acesso em 28 de maio de 2013.

${ }^{72}$ Lei $\mathrm{n}^{\circ}$ 8.935/94, Art. 32. Os notários e os oficiais de registro estão sujeitos, pelas infrações que praticarem, assegurado amplo direito de defesa, às seguintes penas: I - repreensão; II - multa; III suspensão por noventa dias, prorrogável por mais trinta; IV - perda da delegação.
} 
Tribunais Superiores, às quais a Constituição atribui os efeitos acima mencionados"73.

Não obstante o avanço alcançado pela Resolução $n^{\circ} 175$, esta não se encontra livre de ameaças. O PSC - Partido Social Cristão, impetrou Mandado de Segurança ${ }^{74}$ contra a resolução do $\mathrm{CNJ}$ objetivando suspender seus efeitos e sua vigência até que o Congresso Nacional deliberasse sobre a matéria. Para o partido, o CNJ violou o direito líquido e certo de seus filiados de discutir e votar a matéria no âmbito do poder Legislativo. O ministro do Supremo Luiz Fux extinguiu o MS sem analisar o mérito da questão, alegando apenas que o questionamento da medida teria de ser feito por meio de instrumento de controle abstrato de constitucionalidade, e não por mandado de segurança.

Tal acontecimento só corrobora para entendimento de que apesar dos esforços, a atuação vanguardista do judiciário não é suficiente, considerando que parte da sociedade resiste em aceitar a união homoafetiva. Dessa forma, deve ocorrer uma atuação conjunta com o Poder Legislativo para que haja previsão legal.

\subsection{União estável}

Como abordado anteriormente, a sociedade de fato regia as uniões extramatrimoniais entre homem e mulher. A Constituição de 1988 alargou o conceito de família, atribuindo à esse tipo de relacionamento o status de entidade familiar. A partir de então, a união de fato entre homem e mulher passou a ser chamada de união estável.

Entretanto, devido à falta de aplicabilidade da união estável pelos tribunais, que continuavam a fazer uso da sociedade de fato para decidir

\footnotetext{
${ }^{73}$ BUENO, Octávio Ginez de Almeida. O casamento homoafetivo e a Resolução no 175/2013 do Conselho Nacional de Justiça: efetivação dos direitos da pessoa humana. Jus Navigandi, Teresina, ano 18, n. 3612, 22 maio 2013 . Disponível em: 〈http://jus.com.br/revista/texto/24504〉. Acesso em 28 de maio 2013.

${ }^{74}$ STF, Medida Cautelar em Mandado de Segurança 32.077/DF. Relator Min. Luiz Fux, Brasília, Julgado em 28 de maio de 2013.
} 
questões que envolviam a união entre homem e mulher solteiros, foram editadas duas leis para regulamentar o novo instituto.

A Lei no. 8.971, de 29 de dezembro de 1994 regula o direito dos companheiros a alimentos e à sucessão, e dispõe que "na falta de descendentes e de ascendentes, o(a) companheiro(a) sobrevivente terá direito à totalidade da herança" (Art. 2, III).

Todavia, a lei impôs diversas restrições para a configuração da união estável. A companheira, desde que não constituísse nova união estável e comprovada a necessidade, poderia pleitear alimentos caso o homem fosse separado judicialmente, divorciado ou viúvo, ou dele tenha prole. Cabe ressaltar que a lei excluiu os separados de fato. Ademais, estabelece o prazo de 5 anos para o reconhecimento da união estável.

Cabe ressaltar que o prazo estipulado para a configuração da a união estável não é mais exigido. Nessa linha, destaca-se jurisprudência do Tribunal de Justiça do Rio Grande do Sul que entendeu pela existência de união estável em um relacionamento de apenas 1 ano e 8 meses, considerando que os demais requisitos estavam presentes.

UNIÃO ESTÁVEL. PRAZO. Confessada a vida em comum, ainda que por período inferior a dois anos, não há como desqualificar-se o relacionamento pelo fato de varão afirmar que não tinha intenção de casar. Apelo provido ${ }^{75}$.

Em seu voto, a Relatora Desa. Maria Berenice Dias menciona a inexigência de prazo:

"Uma das vitórias da doutrina foi subtrair da lei estipulação do lapso temporal, outorgando ao arbítrio do juízo a configuração da união estável. A Lei $\mathrm{n}^{\circ}$ 9.278/96, ao elencar os requisitos qualificadores do vínculo afetivo apto a produzir efeitos jurídicos, não estipulou prazo para seu reconhecimento" ${ }^{176}$.

A Lei $n^{\circ} 9.278 / 96$, por sua vez, além de conceder direito à herança, teve maior campo de abrangência. Além de não estabelecer prazo para o

\footnotetext{
${ }^{75}$ TJRS. Apelação Cível no 70000908756 Sétima Câmara Cível, Rel. Maria Berenice Dias, Porto Julgado em 10 de maio de 2000.

${ }^{76}$ Ibid.
} 
reconhecimento da união estável, incluiu as relações entre pessoas separadas de fato:

"Para o reconhecimento da união estável, não quantificou prazo de convivência e albergou as relações entre pessoas separadas de fato. Além de fixar a competência das varas de família para o julgamento de litígios, reconheceu o direito real de habitação. Gerou presunção juris et de jure de que os bens adquiridos a título oneroso na constância da convivência são fruto comum, afastando questionamentos sobre a efetiva participação de cada parceiro para proceder à partilha igualitária dos bens" ${ }^{77}$.

Ainda no que se refere à análise da Lei $n^{\circ}$ 9.278/96, o direito real de habitação sobre o imóvel de residência da família na união estável é tutelado pelo seu parágrafo único do art. $7^{\circ}$. Nessa linha, Maria Berenice Dias sustenta que a lei em comento não foi revogada devido à omissão do CC/02 no que diz respeito ao direito real de habitação:

"Como o Código Civil não revogou expressamente esses diplomas legais, é mister reconhecer que não estão derrogadas as prerrogativas previstas na legislação pretérita $^{78 "}$.

Nessa esteira, o enunciado n 117 CJF/STJ da I Jornada de Direito Civil preceitua:

"117 - Art. 1831: o direito real de habitação deve ser estendido ao companheiro, seja por não ter sido revogada a previsão da Lei n. 9.278/96, seja em razão da interpretação analógica do art. 1.831, informado pelo art. $6^{\circ}$, caput, da CF/88".

Entretanto, a questão não é pacífica na doutrina. Há quem sustente a revogação total da Lei 9.278/96 tendo em vista que a união estável foi integralmente versada no Código Civil de 2002, nos seus múltiplos aspectos (regime de bens, direitos e deveres recíprocos, alimentos e sucessão) ${ }^{79}$. Esse argumento encontra fulcro no parágrafo primeiro do art. $2^{\circ}$ da Lei de Introdução às normas do Direito Brasileiro.

No que tange ao regime de bens, caso não haja contrato escrito entre os companheiros, estatui o art. 1.725 do Código Civil que aplicar-se-á às relações patrimoniais o regime da comunhão parcial de bens. Dessa forma,

\footnotetext{
${ }^{77}$ DIAS, Maria Berenice. Manual de Direito das Famílias, p. 169.

${ }^{78}$ Ibid. p. 183.

${ }^{79}$ VARGAS, Fábio de Oliveira. União Homoafetiva: Direito Sucessório e Novos Direitos, p. 63
} 
o companheiro ou companheira terá direito à herança quanto aos bens adquiridos onerosamente na vigência da união estável (Art. 1.790).

Cabe salientar que diferentemente do cônjuge, o companheiro não foi incluído no rol dos herdeiros necessários do Código Civil ${ }^{80}$, restando desprotegido.

Entretanto, em sentido contrário, parte da doutrina sustenta que caso a herança seja composta de bens comuns e particulares, o companheiro terá direito somente à fração dos bens que foram onerosamente adquiridos na constância da união estável, mas estará imune a quaisquer manifestações testamentárias em sentido oposto ${ }^{81}$.

Ainda sobre a possibilidade de o testador suprimir o direito sucessório do companheiro, Carlos Roberto Barbosa Moreira identifica nos incisos do art. 1.790 do Código Civil de 2002 hipóteses de herança necessária. Destaca ainda a proteção especial do Estado prometida à união estável a pela Constituição (art. $226, \S 3^{\circ}$ ), que a reconheceu como entidade familiar.

\footnotetext{
"Se, na hipótese de que ora se cogita, for permitido a um dos companheiros dispor da totalidade de seu patrimônio, o exercício dessa irrestrita liberdade de testar poderá comprometer, em muitos casos, a própria sobrevivência do mais próximo de seus familiares - o resultado, manifestamente indesejável, parece condenar qualquer interpretação em sentido contrário" ${ }^{82}$.
}

Ademais, enquanto o cônjuge deve apenas apresentar a certidão de casamento e de óbito do de cujus para participar da sucessão, a tarefa probatório do companheiro é mais complicada, conforme resta demonstrado pela doutrina abaixo:

"Para participar da sucessão do autor da herança é necessário que a companheira faça a prova da sua qualidade, através de ação própria no juízo competente, porém, não havendo contestação pelos herdeiros e sendo evidente a existência da

\footnotetext{
${ }^{80} \mathrm{CC} / 2002$. Art. 1.845. São herdeiros necessários os descendentes, os ascendentes e o cônjuge.

${ }^{81}$ PEREIRA, Caio Mário da Silva. Instituições de Direito Civil. Vol. VI - Direito das Sucessões 18. ed. - Revista e atualizada por Carlos Roberto Barbosa Moreira. Rio de Janeiro: Editora Forense, 2011, p. 149.

${ }^{82}$ Ibid. p. 150.
} 
união estável somente nesses casos o reconhecimento pode ser feito nos próprios de inventário" 83 .

Cabe destacar ainda que outro fator que diferencia o casamento da união estável é que esta não gera modificação de status civil. Tal distinção contribuí para que ocorra outro aspecto que diferencia o companheiro do cônjuge: a inexigibilidade da outorga uxória.

Apesar de a união estável invocar o regime da comunhão parcial de bens, "no que concerne exclusivamente à divisão dos aquestos, o mesmo não ocorre em relação aos demais aspectos do regime patrimonial atinentes, como, por exemplo, à outorga conjugal para a alienação dos bens (art. 1.647 inciso I, CC) ou para a celebração do contrato de fiança (art. 1.647, inciso III) ${ }^{\prime \prime 84}$. Isso ocorre porque, de acordo com Gustavo Tepedino, o codificador civil determinou a aplicação do regime de comunhão parcial de bens às uniões estáveis apenas "no que couber".

Em função do art. 1.790 do Código Civil de 2002, observa-se que não é atribuído ao companheiro os mesmos direitos sucessórios concedidos ao cônjuge. Conforme disposto pelo artigo, o companheiro participará da sucessão apenas quanto aos bens adquiridos onerosamente na vigência da união.

\begin{abstract}
"Desse modo, comunicam-se os bens havidos pelo trabalho de um ou de ambos durante a existência da união estável, excluindo-se bens recebidos a título gratuito, por doação ou sucessão. Deve ficar claro que a norma não está tratando de meação, mas de sucessão ou herança, independentemente do regime de bens adotado. Por isso, em regra, pode-se afirmar que o companheiro é meeiro e herdeiro, eis que, no silêncio das partes, vale para a união estável o regime da comunhão parcial de bens (art. 1.725 do CC)" ${ }^{185}$.
\end{abstract}

No mesmo sentido, em recente julgado, o Tribunal de Justiça do Estado do Rio de Janeiro, além de confirmar a constitucionalidade do art. 1.790 excluiu a companheira sobrevivente do inventário dos pais do

\footnotetext{
${ }^{83}$ GOMES, Orlando . Sucessões. 14. ed. rev., atual e ampl. Rio de Janeiro: Forense, 2007, p. 68.

${ }^{84}$ TEPEDINO, Gustavo. Controvérsias sobre a tutela sucessória do cônjuge e do companheiro no Direito brasileiro. Revista do Advogado, Ano XXXI, no 112, Julho de 2011, p. 61

${ }^{85}$ TARTUCE, Flávio. Sucessão do Companheiro: O Polêmico Artigo 1.790 e suas Controvérsias Principais, Revista Magister de Direito Civil e Processual Civil no 39 - Nov-Dez/2010, p.102.
} 
companheiro falecido, pois o único bem inventariado foi adquirido por herança, ou seja, não há o requisito da onerosidade.

AGRAVO DE INSTRUMENTO. INVENTÁRIO. HABILITAÇÃO DE COMPANHEIRA DE UM DOS HERDEIROS FALECIDO. DEFERIMENTO. DECISÃO REFORMADA. Recurso contra decisão que deferiu a habilitação de companheira sobrevivente no inventário dos bens dos pais do companheiro falecido, ao fundamento de ser inconstitucional o art. 1.790 do Código Civil. Dispositivo legal que não padece de inconstitucionalidade, devendo ser aplicado ao caso. Assim, o companheiro sobrevivente participa da sucessão do outro tão somente quanto aos bens adquiridos onerosamente durante a união estável. Hipótese em que o único bem inventariado foi adquirido por herança; logo, não foi adquirido onerosamente na vigência da união estável, não fazendo jus a agravada a herdar qualquer quinhão. Provimento do recurso ${ }^{86}$.

Após a análise do caput do art. 1.790, cabe dissecar seus incisos. A sucessão na união estável ocorre da seguinte maneira: I - se concorrer com filhos comuns, terá direito a uma quota equivalente à que por lei for atribuída ao filho; II - se concorrer com descendentes só do autor da herança, tocar-lhe-á a metade do que couber a cada um daqueles;

Quanto aos dois primeiros incisos, cabe observar que o legislador trata de maneira diversa os filhos comuns e os filhos somente do autor da herança. $\mathrm{Na}$ concorrência com estes, o companheiro sobrevivente terá direito à metade do que lhes couber. Trata-se de regra similar ao previsto no art. 1.841, que dispõe sobre a concorrência entre irmãos unilaterais e bilaterais. Por sua vez, a concorrência com os filhos comuns é feita por cabeça, ou seja, todos recebem uma quota igual.

Insta salientar que a lei não prevê a hipótese em que o companheiro concorre com filhos comuns e com descendentes somente do autor da herança, chamados de descendentes exclusivos. É o que se depreende da lição de Orlando Gomes:

"Não há previsão para o caso de concorrer o companheiro com descendentes comuns e descendentes só do autor da herança. Não se pode aplicar a solução de cada situação para os respectivos descendentes, pois haveria desigualdade de

\footnotetext{
${ }^{86}$ TJRJ, Agravo de Instrumento, Processo no 0032299-11.2012.8.19.0000, Rel. Des. Jorge Luiz Habib, Rio de Janeiro, julgado em 26 de fevereiro de 2013.
} 
quinhões hereditários entre os filhos, o que fere a regra constitucional. Por outro lado, a hipótese prevista no inciso III do art. 1.790 destina-se aos casos de concorrência com outros parentes sucessíveis, onde se pode incluir as situações não previstas pelo legislador" ${ }^{87}$.

Flávio Tartuce apresenta três correntes fundamentais para a solução da problemática ${ }^{88}$ :

"1a Corrente: em casos de sucessão híbrida, deve-se aplicar o inciso I do art. 1.790, tratando-se todos os descendentes como se fossem comuns, já que filhos comuns estão presentes.

[...]

2a Corrente - Presente a sucessão híbrida, subsume-se o inciso II do art. 1.790, tratando-se todos os descendentes como se fossem exclusivos (só do autor da herança). Este autor está filiado a tal corrente, assim como Gustavo René Nicolau, Maria Helena Diniz, Sebastião Amorim, Euclides de Oliveira e Zeno Veloso. Ora, como a sucessão é do falecido, em havendo dúvida por omissão legislativa, os descendentes devem ser tratados como sendo dele, do falecido.

3a Corrente - Na sucessão híbrida, deve-se aplicar fórmula matemática de ponderação para solucionar o problema. Entre tantas fórmulas, destaca-se a Fórmula Tusa, com o auxílio do economista Fernando Curi Peres. A fórmula é a seguinte:

$\mathrm{X}=-{ }_{-} \_2(\mathrm{~F}=\mathrm{S}) \_$_ $\mathrm{xH}$

$2(\mathrm{~F}+\mathrm{S})_{2}+2 \mathrm{~F}+\mathrm{S}$

$\mathrm{C}=\ldots 2 \mathrm{~F}+\mathrm{S} \_\mathrm{XX}$

$2(\mathrm{~F}+\mathrm{S})^{\prime \prime 89}$.

Em seguida, conforme preceitua o inciso III do Art. 1.790 do Código Civil de 2002, caso concorra com outros parentes sucessíveis, o companheiro ou companheira terá direito a um terço da herança.

Ana Luiza Maia Nevares destaca que além de receber por herança somente os bens adquiridos a título oneroso na constância da união estável,

\footnotetext{
${ }^{87}$ GOMES, Orlando. . Sucessões. p. 68

${ }^{88}$ TARTUCE, Flávio. Sucessão do Companheiro: O Polêmico Artigo 1.790 e suas Controvérsias Principais, p. 104.

${ }^{89}$ Legenda: $\mathrm{X}=$ o quinhão hereditário que caberá a cada um dos filhos. $\mathrm{C}=\mathrm{o}$ quinhão hereditário que caberá ao companheiro sobrevivente. $\mathrm{H}=$ valor dos bens hereditários sobre os quais recairá a concorrência do companheiro sobrevivente. $\mathrm{F}=$ número de descendentes comuns com os quais concorra o companheiro sobrevivente. $\mathrm{S}=\mathrm{o}$ número de descendentes exclusivos com os quais concorra o companheiro sobrevivente.
} 
o companheiro concorre na sucessão inclusive com os colaterais, diferentemente do cônjuge ${ }^{90}$.

Existem julgados que reconhecem a inconstitucionalidade do inciso III. Flávio Tartuce é favorável à tese de inconstitucionalidade somente deste inciso, por ser o mesmo desproporcional, desprestigiando a união estável ${ }^{91}$, entretanto preserva o art. 1.790 e seus demais incisos.

Por fim, prosseguindo na análise do art. 1.790, reza seu inciso IV que na falta de herdeiros sucessíveis, o companheiro terá direito à totalidade da herança. Segundo Orlando Gomes ${ }^{92}$, assegura-se ao companheiro sobrevivente a totalidade dos bens, adquiridos de maneira onerosa ou não. Tal afirmação encontra respaldo no art. 1.844, no qual a herança só é destinada ao Estado caso não haja cônjuge, companheiro ou parente sucessível.

\footnotetext{
${ }^{90}$ NEVARES, Ana Luiza Maia. A Tutela Sucessória do Cônjuge e do Companheiro na Legalidade Constitucional, p. 75

${ }^{91}$ TARTUCE, Flávio. Sucessão do Companheiro: O Polêmico Artigo 1.790 e suas Controvérsias Principais , p. 107.

${ }^{92}$ GOMES, Orlando. . Sucessões. p. 68
} 


\section{O reconhecimento da união homoafetiva como entidade familiar e a sucessão entre pares do mesmo sexo}

\subsection{ADPF $n=132$ e ADI $n=4.277$}

Em 05 de maio de 2011, no julgamento conjunto da Arguição de Descumprimento de Preceito Fundamental (ADPF) no 132/RJ e da Ação Direta de Inconstitucionalidade (ADI) $\mathrm{n}^{\circ}$ 4.277/DF, o Supremo Tribunal Federal, por unanimidade, concedeu ao art. 1.723 do Código Civil de 2002 interpretação conforme à Constituição de modo a excluir qualquer significado que impeça o reconhecimento da união contínua, pública e duradoura entre pessoas do mesmo sexo como entidade familiar.

Com o intuito de evitar qualquer tipo de interpretação do art. 1.723 do Código Civil em sentido preconceituoso ou discriminatório faz-se necessária a utilização da técnica de "interpretação conforme à Constituição". De acordo com o Supremo, o reconhecimento da união estável homoafetiva não deve se diferenciar em nenhum aspecto da união heteroafetiva.

Não há dúvidas de que a decisão do Supremo Tribunal Federal na ADI $n^{\circ} 4.277$ e ADPF $n^{\circ} 132$ representou um marco histórico no direito brasileiro:

"A comunicação feita pelo Presidente do STF a todos os tribunais e juízes reafirma a eficácia contra todos e o efeito vinculante do julgamento e assevera: Este reconhecimento há de ser feito segundo as mesmas regras e com as mesmas consequências da união estável homoafetiva" ${ }^{93}$.

No que tange aos efeitos da decisão, consoante o disposto pelo parágrafo único do art. 28 da Lei no 9.868/99, "a declaração de constitucionalidade ou de inconstitucionalidade, inclusive a interpretação conforme a Constituição e a declaração parcial de inconstitucionalidade sem redução de texto têm eficácia contra todos e efeito vinculante em

\footnotetext{
93 DIAS, Maria Berenice. A Consagração Constitucional da Homoafetividade. Revista Magister de Direito Civil e Processual Civil, v. 42, maio/junho 2011, p. 95
} 
relação aos órgãos do Poder Judiciário e à Administração Pública

federal, estadual e municipal". (grifos nossos)

Na dicção expressa no artigo em comento, a decisão além eficácia contra todos possui efeito vinculante, ou seja, nenhum órgão do Poder Judiciário ou da Administração Pública poderá decidir de maneira contrária à decisão, sob pena de reclamação.

O Poder Legislativo, entretanto, não se encontra vinculado à decisão do Supremo, podendo, inclusive, editar nova lei em sentido contrário. Entendimento diverso significaria o "inconcebível fenômeno da fossilização da Constituição"94.

Oportunamente, Luís Roberto Barroso expõe:

"O Poder Legislativo ficou excluído da dicção e do alcance do efeito vinculante previsto no parágrafo único do art. 28 da Lei n. 9.868 e no art. $102, \S 2^{\circ}$ da Constituição Federal. Em certos sistemas constitucionais, a decisão de inconstitucionalidade impede o legislador futuro de editar norma de conteúdo igual ao análogo ao que foi rejeitado. Embora pareça intuitivo que o legislador assim deva proceder, nem sempre é o que se passa. No direito brasileiro, a rigor técnico, não há como impedir que o órgão legislativo volte a prover acerca da matéria e, ao fazê-lo, incorra em inconstitucionalidade da mesma natureza. Por tal razão, não caberá reclamação perante Supremo Tribunal Federal na hipótese de edição de norma de conteúdo idêntico ou similar, por não estar o legislador vinculado à motivação do julgamento sobre a validade do diploma legal precedente. O caso será de ajuizamento de nova ação direta" $"$.

\subsection{O Direito Sucessório na União Homoafetiva}

Considerando a decisão do Supremo na ADPF no 132 e da ADI n 4.277 e principalmente a Resolução $n^{\circ} 175$ do $\mathrm{CNJ}$, a sucessão do companheiro homoafetivo observa o mesmo trâmite da sucessão no casamento e na união estável entre o homem e a mulher, já que casais do mesmo sexo desde 14 de maio de 2013 passaram a ter a opção de escolher a forma de legalizar sua união, seja por união estável ou casamento civil.

O fato é que com a Resolução $n^{\circ} 175$, os tribunais poderão resolver as demandas que lhe são submetidas com maior clareza e uniformidade.

\footnotetext{
${ }^{94}$ LENZA, Pedro. Direito Constitucional Esquematizado. 13 ed. rev. e ampl. São Paulo: Saraiva, 2009 , p. 238

95 BARROSO, Luís Roberto. O Controle de Constitucionalidade no Direito Brasileiro. Ed. Saraiva. $4^{\mathrm{a}}$ edição. São Paulo, 2009. p. 205
} 
Ainda assim, cabe apresentar como os Tribunais de Justiça, o STJ e o STF as vêm solucionando. Dessa forma, propõe-se observar a evolução da jurisprudência acerca da sucessão na união homoafetiva, desde quando ainda não havia sido considerada entidade familiar, que ocorreu em maio de 2011, até os dias atuais.

Anteriormente à decisão do STF na ADPF 132 e ADI 4.277, a união homossexual não era compreendida como entidade familiar e a competência para julgar as ações era da Vara Cível e não da Vara de Família. A jurisprudência ainda aplicava a sociedade de fato nas relações entre pares do mesmo sexo, como podemos observar no julgado abaixo, datado de 07 de novembro de 2007:

ARROLAMENTO DE BENS. UNIÃO HOMOSSEXUAL. INCOMPETÊNCIA ABSOLUTA DO JUÍZO DE FAMÍLIA. NULIDADE DOS ATOS DECISÓRIOS.A união entre pessoas do mesmo sexo não é considerada no direito pátrio como concubinato ou união estável, logo, não tem caráter de entidade familiar, mas não impede que a referida união possa configurar-se como sociedade de fato, de natureza civil, ao amparo do disposto no artigo 981 do Código Civil.Com efeito, as consequências jurídicas desse relacionamento de ordem afetivo/sexual e formação do patrimônio, em especial o direito à partilha de bens, em caso de vir a mesma a ser dissolvida pelo falecimento de um deles ou o rompimento espontâneo da relação que lhe deu origem, deverão ser dirimidas no Juízo Cível.A declaração de incompetência absoluta, com a determinação de remessa dos autos à justiça competente, acarreta a declaração de nulidade de todos os atos decisórios. RECONHECIMENTO DA INCOMPETÊNCIA ABSOLUTA DO JUÍZO DE FAMÍLIA. ${ }^{96}$

Entretanto, mesmo antes do julgamento da ADPF 132 E ADI 4.277 pela Suprema Corte, o mesmo Tribunal de Justiça do Estado do Rio de Janeiro, com base em precedentes do STJ, TJRJ e TJRS ${ }^{97}$, reconheceu a união homoafetiva entre companheiras, aplicando as regras da união estável, afastando o instituto da sociedade de fato. Frisou-se a impossibilidade de dar tratamento diferenciado entre união heterossexual e união homossexual, vedada constitucionalmente. Ademais, foi concedida a

\footnotetext{
96 TJRJ - Sexta Câmara Cível - Agravo de Instrumento n 0012512-06.2006.8.19.0000 (2006.002.17965) - Relator Desembargador Francisco de Assis Pessanha, Rio de Janeiro, Julgado em 07 de novembro de 2007.

97 STJ REsp 1026981/RJ, Rel. Min. Nanci Andrighi, julgado em 22/06/2010. TJRJ AI 2009.002.13072, Rel. Des. Roberto de Abreu e Silva, julgado em 09/06/2009. TJRS AC 70005488812,Rel. Des. Jose Carlos Teixeira Giorgis, julgada em 25/06/2003.
} 
totalidade da herança à companheira sobrevivente, mesmo diante da existência de colaterais (irmãos da falecida):

\section{RELACAO HOMOAFETIVA .UNIAO ESTAVEL POST MORTEM RECONHECIMENTO DA UNIAO. INVENTARIO. DIREITO A HERANCA. RESERVA DE BENS.}

APELAÇÃO CÍVEL. Ação declaratória de reconhecimento de união homoafetiva. Direito à sucessão. Imóvel adquirido pelas companheiras em partes iguais. Sentença parcialmente procedente. Reconhecimento da sociedade de como união homoafetiva e da parcela de apenas 20,62\% do imóvel adquirido pelo casal na constância da união. Pedido da autora relativo à herança julgado improcedente. Pedido contraposto dos réus, irmãos da falecida, pela fixação de taxa de ocupação julgado improcedente. Reforma do decisum. Óbito ocorrido na vigência da Lei 8.971/94 que deve ser aplicada analogicamente ao caso vertente, sob pena de violação da isonomia e da dignidade da pessoa humana. Parcela de $50 \%$ do único imóvel do casal que já integrava o patrimônio da autora, eis que esta figura no RGI como co-proprietária do referido bem. Direito da autora à totalidade da herança deixada por sua companheira, que não deixou ascendentes nem descendentes, representada pela outra metade do imóvel (50\%), na forma do art. $2^{\circ}$, III do antecitado diploma legal. Aplicação das regras da união estável às relações homoafetivas, mormente quando as conviventes se uniram como entidade familiar e não como meras sócias. Lacuna na lei que deve ser dirimida a luz dos princípios gerais e do direito comparado. Impossibilidade de dar tratamento diferenciado entre união heterossexual e união homossexual, eis que a própria Constituição veda expressamente a segregação da pessoa humana por motivo sexo, origem, raça, cor, idade ou quaisquer outras formas de discriminação. Precedentes jurisprudenciais do Tribunal Gaúcho e do STJ nesse mesmo sentido. APELOS CONHECIDOS. DESPROVIMENTO DO APELO DOS RÉUS, DANDO-SE PROVIMENTO AO APELO DA PARTE AUTORA. ${ }^{98}$

A ementa a seguir trata de agravo de instrumento julgado pelo

Tribunal de Justiça do Rio Grande do Sul interposto pelo espólio do falecido da decisão que indeferiu a partilha de bens por metade entre o cônjuge e a ascendente do de cujus.

Não há discussão quanto à existência da união homoafetiva, frente ao seu reconhecimento judicial anterior. $O$ tribunal, entretanto, não reconheceu o direito à metade da herança pleiteada pelo agravante, que nas razões defende a divisão do patrimônio conforme o art. 1.837 do $\mathrm{CC}^{99}$. O agravante sustenta que não é cabível fazer distinções entre cônjuge e

\footnotetext{
98 TJRJ - Décima Nona Câmara Cível - Apelação Cível n 0007309-38.2003.8.19.0204 - Relator Desembargador Ferdinaldo do Nascimento, Rio de Janeiro, Julgado em 28 de setembro de 2010.

99 Art. 1.837. Concorrendo com ascendente em primeiro grau, ao cônjuge tocará um terço da herança; caber-lhe-á a metade desta se houver um só ascendente, ou se maior for aquele grau.
} 
companheiro. Cita ainda o art. 226, $\S 3^{\circ}$, da $\mathrm{CF} / 88$, doutrina e jurisprudência no sentido da inconstitucionalidade do art. 1.790 do CC.

O Relator negou provimento ao agravo, decidindo que o companheiro concorre na forma do art. 1.790 , III, do CC/02 ${ }^{100}$, e não como pretendido. Citou ainda o julgamento de incidente de inconstitucionalidade julgado pelo Órgão Especial do Tribunal Pleno ${ }^{101}$, no qual rejeitou a inconstitucionalidade do art. 1.790, III do CC/02.

SUCESSÃO. INVENTÁRIO. UNIÃO ESTÁVEL HOMOAFETIVA. VÍNCULO RECONHECIDO JUDICIALMENTE. O DIREITO DO COMPANHEIRO À HERANÇA LIMITA-SE AOS BENS ADQUIRIDOS A TÍTULO ONEROSO NA VIGÊNCIA DA UNIÃO ESTÁVEL. CONCORRÊNCIA SUCESSÓRIA DO COMPANHEIRO. EXEGESE DO ART. 1.790 DO CÓDIGO CIVIL. PRECEDENTES. AGRAVO DESPROVIDO ${ }^{102}$.

No mesmo sentido, a mesma Oitava Câmara do TJRS, dessa vez em julgado posterior à decisão do STF na ADPF 132, manteve o entendimento sobre a possibilidade de união estável entre pessoas do mesmo sexo e continuou à aplicar o art. 1.790 do $\mathrm{CC} / 02$ referente à sucessão do companheiro.

Ementa: APELAÇÃO CÍVEL. AÇÃO DE RECONHECIMENTO
DE UNIÃO ESTÁVEL HOMOAFETIVA. POSSIBILIDADE.
POSICIONAMENTO CONSAGRADO NO JULGAMENTO DA ADIN N 4277
E DA ADPF N ${ }^{\circ}$ 132. DIREITOS SUCESSÓRIOS. PREQUESTIONAMENTO.
1. Tendo em vista o julgamento da ADIn $\mathrm{n}^{\circ} 4277$ e da ADPF $\mathrm{n}^{\circ}$ 132, resta
superada a compreensão de que se revela juridicamente impossível
o reconhecimento de união estável, em se tratando de duas pessoas do
mesmo sexo. 2. Na espécie, o conjunto probatório é robusto no sentido da
caracterização do relacionamento estável, nos moldes do art. 1.723 do CC, razão
por que deve ser emprestado à relação havida entre a recorrente e a companheira
falecida tratamento equivalente ao que a lei confere à união estável havida
entre homem e mulher, inclusive no que se refere aos direitos sucessórios sobre
as duas casas construídas com esforço comum, o que foi reconhecido
judicialmente, na forma do art. 1.790, III, do CC (pois concorre a insurgente com
a genitora da falecida). 3. O magistrado não está obrigado a se manifestar sobre
todos os dispositivos legais invocados pelas partes, necessitando, apenas, indicar

\footnotetext{
${ }^{100}$ Art. 1.790. A companheira ou o companheiro participará da sucessão do outro, quanto aos bens adquiridos onerosamente na vigência da união estável, nas condições seguintes: [...] III - se concorrer com outros parentes sucessíveis, terá direito a um terço da herança;

${ }^{101}$ TJRS - Incidente de inconstitucionalidade $\mathrm{n}^{\circ}$ 70029390374, j. em 09.11.09.

102 TJRS - Oitava Câmara Cível - Agravo de Instrumento $\mathrm{n}^{\circ}$ 70039688452, Relator Luiz Ari Azambuja Ramos, Rio Grande do Sul, Julgado em 24 de fevereiro de 2011.
} 
o suporte jurídico no qual embasa seu juízo de valor, entendendo ter dado à matéria à correta interpretação jurídica. APELO PROVIDO ${ }^{103}$.

Por sua vez, o recente julgado do Tribunal de Justiça do Estado de São Paulo afastou a aplicação do art. 1.790. Foi concedida a totalidade da herança ao companheiro sobrevivente em razão da ausência de descendentes e ascendentes. Contudo, o falecido deixou colaterais, que foram afastados da sucessão apesar da lei incluí-los. Ambos viviam em união estável desde 1980, e diante do término não desejado em razão da morte do companheiro, o agravado pleiteou a partilha do patrimônio comum apurado, com esforço comum, ao longo desse tempo de convivência.

Em notável decisão, o relator salientou que a Constituição de 1988 afastou em nome da dignidade da pessoa a possibilidade de se fazer distinção entre as pessoas, tal se aplicando, também, no tocante às questões de sexo. Destacou ainda que o juiz não pode se omitir da análise do caso com pretexto de que não há legislação prevendo a situação.

Merece destaque a aplicação analógica do art. 1.829, III do Código Civil, que dispõe sobre a sucessão legítima do cônjuge. O Tribunal de Justiça do Estado de São Paulo, ao definir a partilha aplicou as regras referentes à sucessão do cônjuge, excluindo os demais herdeiros colaterais da sucessão.

ARROLAMENTO DE BENS Reconhecimento de união homoafetiva no curso da demanda Possibilidade Companheiro que figura como dependente nos cadastros da Previdência Social Ausência de descendentes e ascendentes - Companheiro que deve ser chamado a suceder à totalidade da herança deixada Aplicação analógica do art. 1.829, inciso III, do Código Civil - Liminar cassada - Decisão mantida AGRAVO NÃO PROVIDO. ${ }^{104}$

A ausência de uniformidade entre tais decisões acerca da aplicação ou não do art. 1.790 ocorre independentemente da orientação sexual dos

\footnotetext{
${ }^{103}$ TJRS. Apelação Cível No 70045194677, Oitava Câmara Cível, Relator Ricardo Moreira Lins Pastl, Rio Grande do Sul, 2 de março de 2012.

${ }^{104}$ TJSP - $10^{\mathrm{a}}$ Câmara de Direito Privado - Agravo de Instrumento n ${ }^{\circ}$ 0119122-90.2012.8.26.0000

- Rel. Elcio Trujillo, São Paulo, 30 de abril de 2013.
} 
companheiros, tendo em vista que o próprio artigo é controverso, uma vez que o presente no artigo apresenta supostas desvantagens na sucessão do companheiro comparada a sucessão do cônjuge.

Ante o exposto podemos concluir que com a possibilidade de escolha trazida pela Resolução $\mathrm{n}^{\circ} 175$ do $\mathrm{CNJ}$, a tendência é que tais questões não sejam submetidas em grande escala aos tribunais, uma vez que é desnecessário o ajuizamento de demandas no Poder Judiciário pleiteando a união homoafetiva. Assim sendo, a sucessão do companheiro ou cônjuge homoafetivo dependerá exclusivamente do regime de bens. 


\section{Conclusão}

O ordenamento jurídico brasileiro veda preconceitos de origem, raça, sexo, cor, idade e quaisquer outras formas de discriminação, conforme disposto no inciso IV do art. $1^{\circ}$ da Carta Magna. Sendo tal rol claramente exemplificativo, podemos concluir que é vedada também a discriminação em razão da orientação sexual.

No primeiro capítulo, frisamos que a família homoafetiva não comporta tratamento desigual. Destacamos também que homossexualidade não é uma patologia e muito menos uma doença passível de cura.

No que diz respeito à união homoafetiva sob a ótica constitucional, primeiramente procuramos embasar a possibilidade no princípio da isonomia e da igualdade, preceituados pelo art. $5^{\circ}$ da Constituição Federal, que dispõe que todos são iguais perante a lei, sem distinção de qualquer natureza. Deste modo entendemos que a união civil entre pessoas do mesmo sexo é possível, considerando que não pode haver tratamento diverso em virtude da orientação sexual de cada casal.

Em seguida, com fundamento em outros princípios constitucionais, tais como o princípio da dignidade da pessoa humana, da intimidade, da privacidade e princípios do direito de família, dentro os quais o princípio da igualdade de respeito a diferença, do pluralismo das entidades familiares e da afetividade, concluímos que a família homoafetiva merece tratamento igualitário.

Apesar de ter garantido direitos fundamentais de suma importância, o constituinte intencionalmente reconheceu apenas a união estável entre homem e mulher, conforme estatui o $\S 3^{\circ}$ do art. 226 da CRFB, deixando à margem do direito a união entre pessoas do mesmo sexo. Entretanto, com respaldo na doutrina e na jurisprudência concluímos que o dispositivo 
constitucional em comento consiste em cláusula geral de inclusão ${ }^{105}$, ou seja, caso sejam preenchidos os requisitos de afetividades, estabilidade e ostensibilidade, a união estável deve ser reconhecida. Ademais, a existência de uma vedação implícita à união entre pessoas do mesmo sexo implicaria em ofensa a diversos princípios constitucionais, tais como o da igualdade, $o$ da não discriminação, o da dignidade da pessoa humana e os do pluralismo e livre planejamento familiar ${ }^{106}$.

Não obstante dos esforços da doutrina e da jurisprudência em buscar respaldo legal que sustente a união homoafetiva, o fato é que não há lei expressa que a regule. A responsabilidade pela ausência de previsão legal é atribuída ao legislativo, que por diversas razões, dentre as quais a presença de um conservadorismo exacerbado, a falta de interesse e o receio em desagradar o eleitorado, está em mora com parcela da população.

A displicência do legislador acarreta a atuação do Poder Judiciário, já que conforme preceitua o art. 126 do Código de Processo Civil, o magistrado não pode se eximir de julgar alegando lacuna ou obscuridade na lei. Na falta de norma legal, deverá recorrer à analogia, aos costumes e aos princípios gerais de direito.

Isto posto, destacamos o papel contramajoritário exercido pelo STF, uma vez que assegura direitos das minorias, intrinsecamente vulneráveis. O Estado não pode ser democrático apenas formalmente, ou seja, se interessar apenas por questões que envolvem a maioria. Por essa razão, é de suma importância um Poder Judiciário vanguardista, atento à mudanças que ocorrem naturalmente em nossa sociedade e disposto a concretizar direitos pertencentes às minorias.

No que tange ao direito sucessório, iniciamos com o estudo da sociedade de fato, instituto já aplicado pelo judiciário à união homoafetiva com o intuito de tutelar interesses dos companheiros, principalmente

\footnotetext{
${ }^{105}$ DIAS, Maria Berenice. Manual de Direito das Famílias, p. 198.

${ }^{106}$ STJ, Resp. n. 183.378, Relator Ministro Luís Felipe Salomão, Brasília, 25 de out. de 2011.
} 
relacionados ao patrimônio comum. Foi comprovada a inadequação da aplicação da sociedade de fato aos companheiros homoafetivos, uma vez que além da impossibilidade de ocorrer uma sucessão propriamente dita, não leva em consideração o afeto presente na relação entre casais do mesmo sexo, tendo em vista que o instituto pertence ao direito obrigacional, e trata os companheiros como meros "sócios".

Em relação à sucessão do cônjuge e do companheiro, dois artigos do Código Civil de 2002 apresentam maior controvérsia e divergência tanto na doutrina quanto na jurisprudência: art. 1829, I e art. 1.790.

Trata o art. 1.829, I da concorrência entre cônjuges e descendentes. Após analisar três correntes doutrinárias completamente diversas acerca da interpretação do artigo em comento, a Ministra Nancy Andrighi, relatora do Recurso Especial $\mathrm{n}^{\circ}$ 992.749, partindo do pressuposto de que há concorrência com descendentes e que o de cujus deixou bens particulares, apresentou o seguinte entendimento: a) quanto à comunhão parcial de bens, esta não pode ser confundida com a comunhão universal após a morte, devendo ser respeitada a vontade das partes. Dessa forma, além de meeiro, o cônjuge concorre com os descendentes quanto aos bens comuns, mas não herda bens particulares; b) já no regime da separação de bens (legal ou convencional), salvo previsão contrária no pacto antenupcial, o cônjuge não é meeiro nem herdeiro. Os bens deixados pelo de cujus serão divididos entre os descendentes; c) por fim, o regime da comunhão universal de bens não apresenta controvérsia entre as correntes doutrinárias. O cônjuge é apenas meeiro.

No que diz respeito às diferenças entre cônjuge e companheiro, primeiramente, cabe observar que encontramos as regras da sucessão do companheiro no capítulo das disposições gerais da sucessão em geral (Capítulo I do Título I do Livro V) enquanto a sucessão do cônjuge é regulada no capítulo da ordem da vocação hereditária, presente no título que se refere à sucessão legítima. 
Desta forma, o cônjuge é herdeiro necessário, ocupando o terceiro lugar na linha de sucessão. Apesar de parte da doutrina identificar hipóteses de herança necessária na união estável ${ }^{107}$, não há menção expressa ao companheiro no rol de herdeiros necessários previsto pelos arts. 1.829 e 1.845 do $\mathrm{CC} / 02$.

Por sua vez, o art. 1.790 do CC/02 dispõe que a companheira ou o companheiro participará da sucessão do outro apenas quanto aos bens adquiridos onerosamente na vigência da união estável. Isso significa que comunicam-se apenas os bens adquiridos por esforço comum durante a constância da união, excluindo bens recebidos por doação ou sucessão. Cabe ressaltar que o requisito da onerosidade não foi exigido pelo dispositivo que trata da sucessão do cônjuge.

O inciso III do mesmo art. 1.790 dispõe sobre a concorrência do companheiro com outros parentes sucessíveis. Nesse caso, o companheiro terá direito a um terço da herança. Como vimos, parte da doutrina é inclusive favorável à inconstitucionalidade do presente inciso, devido à sua desproporcionalidade, uma vez que na sucessão o cônjuge não concorre com colaterais.

Ademais, o cônjuge sobrevivente não precisa fazer prova do esforço comum na construção do patrimônio. Para participar da sucessão basta que apresente a certidão de casamento e a certidão de óbito do de cujus. $\mathrm{Na}$ união estável, caso as partes não tenham firmado contrato, a tarefa probatória é mais complexa, sendo necessário que a companheira faça a prova da sua qualidade, através de ação própria no juízo competente ${ }^{108}$.

Concluímos, portanto, que o companheiro encontra-se em desvantagem comparado ao cônjuge no que diz respeito à sucessão. Tal desproporcionalidade não deveria existir, uma vez que tanto o casamento

\footnotetext{
${ }^{107}$ PEREIRA, Caio Mário da Silva. Instituições de Direito Civil. Vol. VI - Direito das Sucessões, p. 150 .

${ }^{108}$ GOMES, Orlando . Sucessões, p. 68.
} 
quanto a união estável são entidades familiares e merecem tutela jurídica igualitária.

Por fim, cumpre destacar que apesar das diferenças entre casamento e união estável, a Resolução $n^{\circ} 175$ do CNJ ao vedar a recusa dos cartórios em celebrar casamento civil ou converter a união estável em casamento entre pessoas do mesmo sexo, proporcionou o poder de escolha. Antes essa opção não existia, uma vez que a decisão do STF no julgamento da ADPF $\mathrm{n}^{\circ} 132$ e da ADI no 4.277 apesar de inovadora e de suma importância na concretização dos direitos de pares do mesmo sexo, não mencionou expressamente a possibilidade de casamento civil entre pessoas do mesmo sexo. Dessa forma, as autoridades competentes resistiam em converter a união estável entre pessoas do mesmo sexo em casamento civil, apesar da conversão ser garantida pelo art. $226, \S 3^{\circ}$ da CRFB/88.

A Resolução $n^{\circ} 175$ do CNJ pôs fỉm a falta de uniformidade dos cartórios, concretizando direitos perseguidos há muitos anos pelas famílias homoafetivas. Observada a evolução da doutrina e jurisprudência, espera-se que em breve, que a legislação brasileira permita o casamento civil entre pessoas do mesmo sexo. 


\section{Referências Bibliográficas}

BARROSO, Luís Roberto. O Controle de Constitucionalidade no Direito Brasileiro. Ed. Saraiva. 4a edição. São Paulo: 2009.

BARROSO, Luis Roberto; MENDONÇA, Eduardo. O STF entre seus papéis contramajoritário e representativo. Artigo publicado em 04/01/2013. Disponível em <http://www.osconstitucionalistas.com.br/o-stfentre-seus-papeis-contramajoritario-e-representativo>. Acesso em 03 de junho de 2013.

BUENO, Octávio Ginez de Almeida. O casamento homoafetivo e a Resolução $n^{o}$ 175/2013 do Conselho Nacional de Justiça: efetivação dos direitos da pessoa humana. Jus Navigandi, Teresina, ano 18, n. 3612, 22 maio $2013 . \quad$ Disponível em: <http://jus.com.br/revista/texto/24504>. Acesso em 28 maio 2013.

DIAS, Maria Berenice. A Consagração Constitucional da Homoafetividade. Revista Magister de Direito Civil e Processual Civil, v. 42, maio/junho 2011, p. 95

DIAS, Maria Berenice. Manual de Direito das Famílias. Editora Revista dos Tribunais, 6ª Edição, São Paulo: 2010.

DIAS, Maria Berenice. Ponto Final. Disponível em <http://www.mariaberenicedias.com.br/uploads/2_-_ponto_final.pdf>.

Acesso em 04 de junho de 2013.

DIAS, Maria Berenice. Quer casar comigo?. Artigo publicado em 20/05/2013. Disponível em <http://direitohomoafetivo.com.br/anexos/artigo/93_ae90d48e5fc 797525b 95497e6f69d511.pdf>. Acesso em 29 de maio de 2013

DIAS, Maria Berenice. Um novo direito: Direito Homoafetivo. Disponível em <http://www.mariaberenice.com.br/uploads/55_-_um_novo_direito__direito_homoafetivo.pdf>. Acesso em 05 de junho de 2013

GOMES, Orlando. . Sucessões. 14. ed. rev., atual e ampl. Rio de Janeiro: Forense, 2007.

LENZA, Pedro. Direito Constitucional Esquematizado. 13 ed. rev. e ampl. São Paulo: Saraiva, 2009 
LIMA, Wládia Carvalho de Maracaba Calheiros de. Casamento Homossexual sob a Perspectiva da Mutação Constitucional. Revista Jurídica Consulex, Ano XV, n 339, 1 de março de 2011

LÔBO, Paulo Luiz Netto. Direito Civil: Famílias. $4^{a}$ Edição. São Paulo: Saraiva, 2011.

NEVARES, Ana Luiza Maia. A Tutela Sucessória do Cônjuge e do Companheiro na Legalidade Constitucional. Rio de Janeiro: Renovar, 2004.

PEREIRA, Caio Mário da Silva. Instituições de Direito Civil. Vol. VI Direito das Sucessões - 18. ed. - Revista e atualizada por Carlos Roberto Barbosa Moreira. Rio de Janeiro, Editora Forense, 2011.

RABELO, César Leandro de Almeida; VIEGAS, Cláudia Mara de Almeida Rabelo; POLI, Leonardo Macedo. A Inclusão dos Excluídos: a Regulamentação Jurisdicional para a Família Homoafetiva e o Ativismo Judicial. Revista Direito das Famílias e Sucessões no 27 - Abr-Maio/2012Porto Alegre: Magister; Belo Horizonte: IBDFAM.

TARTUCE, Flávio. Sucessão do Companheiro: O Polêmico Artigo 1.790 e suas Controvérsias Principais. Revista Magister de Direito Civil e Processual Civil no 39 - Nov-Dez/2010.

TEPEDINO, Gustavo. Controvérsias sobre a tutela sucessória do cônjuge e do companheiro no Direito brasileiro. Revista do Advogado, Ano XXXI, $\mathrm{n}^{\mathrm{o}}$ 112, Julho de 2011.

VARGAS, Fábio de Oliveira. União Homoafetiva: Direito Sucessório e Novos Direitos, $2^{\text {a }}$ Edição, Curitiba: Editora Juruá, 2011.

STF, ADPF no 132, Relator Ministro Ayres Britto, Brasília, 05 de maio de 2011

STJ, Resp. $\mathrm{n}^{\circ}$ 1.183.378 - RS (2010/0036663-8), Relator Ministro Luis Felipe Salomão, Brasília, 25 de out. de 2011.

TJRJ - Décima Oitava Câmara Cível - Apelação no 036691912.2008.8.19.0001 - Relator Jorge Luiz Habib, Rio de Janeiro, 11 de set. de 2012. 
STJ - Terceira Turma - Recurso Especial no 992.749 - MS (2007/02295979) Relatora Ministra Nancy Andrighi, Brasília, 01 de dez. de 2009

TJRJ, Agravo de Instrumento, Processo $\mathrm{n}^{\circ}$ 0032299-11.2012.8.19.0000, Relator Desembargador Jorge Luiz Habib, Rio de Janeiro, 26 de dez. de 2013.

TJRJ - Sexta Câmara Cível - Agravo de Instrumento n ${ }^{\circ} 0012512$ 06.2006.8.19.0000 (2006.002.17965), Relator Desembargador Francisco de Assis Pessanha, Rio de Janeiro, 07 de nov. de 2007.

TJRJ - Décima Nona Câmara Cível - Apelação Cível n 000730938.2003.8.19.0204 - Relator Desembargador Ferdinaldo do Nascimento, Rio de Janeiro, 28 de set. de 2010.

TJRS - Oitava Câmara Cível - Agravo de Instrumento n ${ }^{\circ} 70039688452$, Relator Luiz Ari Azambuja Ramos, Rio Grande do Sul, 24 de fev. de 2011.

TJRS, Sétima Câmara Cível. APELAÇÃO CÍVEL nº 70000908756, Relatora Desembargadora Maria Berenice Dias, Rio Grande do Sul, 10 de maio de 2000.

TJSP - $10^{\text {a }}$ Câmara de Direito Privado - Agravo de Instrumento no 0119122 90.2012.8.26.0000 - Relator Elcio Trujillo, São Paulo, 30 de abril de 2013.

TJRS, Oitava Câmara Cível, Apelação Cível No 70045194677, Relator: Ricardo Moreira Lins Pastl, Rio Grande de Sul, 22 de mar. de 2012. 